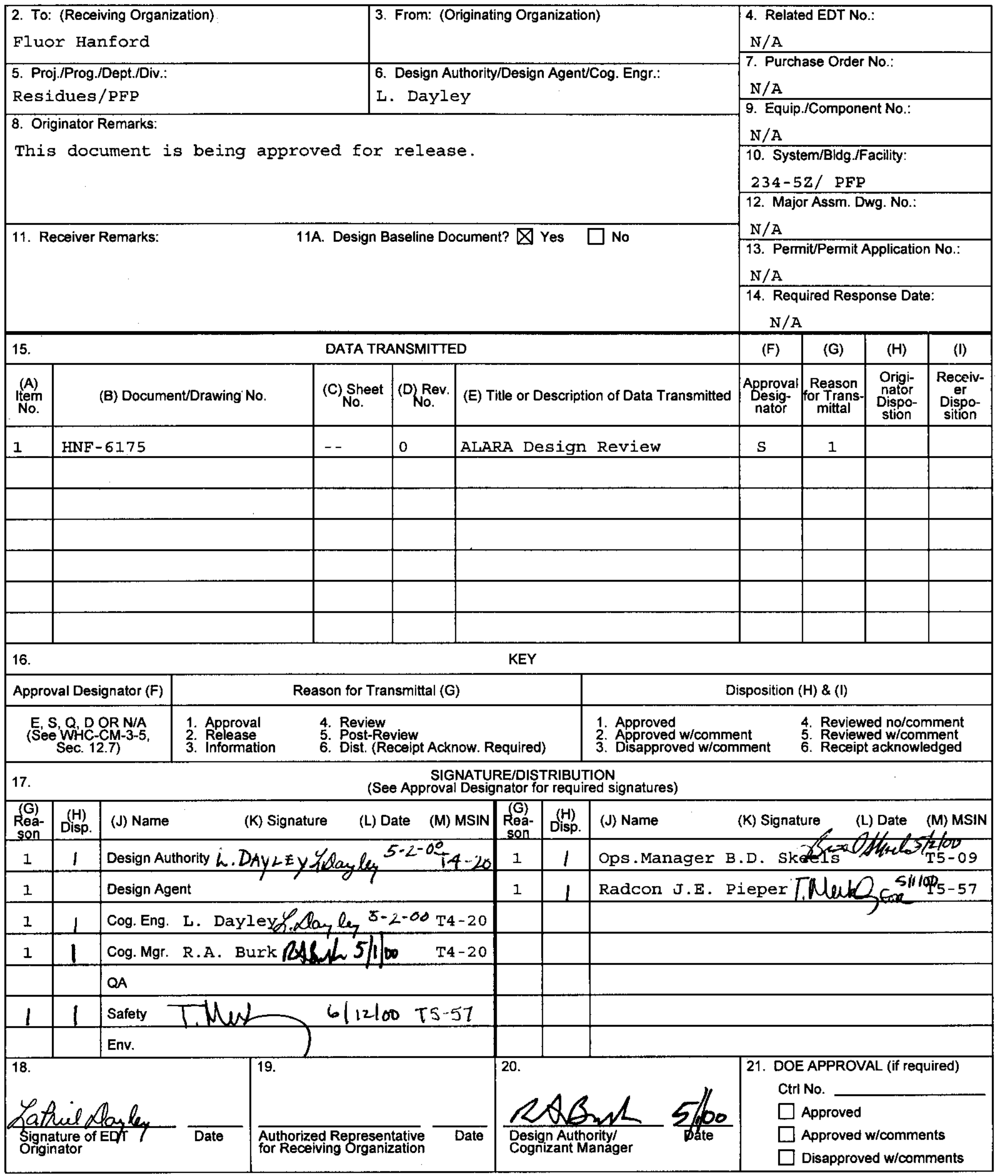




\section{ALARA Design Review for the Resumption of the Plutonium Finishing Plant Cementation Process Project Activities}

Prepared for the U.S. Department of Energy Assistant Secretary for Environmental Management

Project Hanford Management Contractor for the

U.S. Department of Energy under Contract DE-AC06-96RL13200

Firor Hanford

P.O. Box 1000

Richland, Washington 
HNF-6175

Revision 0

EDT *******

627551

\section{ALARA Design Review for the Resumption of the Plutonium Finishing Plant Cementation Process Project Activities}

P Volza

Project Enhancement Corporation

Date Published

April 2000

Prepared for the U.S. Department of Energy

Assistant Secretary for Environmental Management

Project Hanford Management Contractor for the

U.S. Department of Energy under Contract DE-AC06-96RL13200

Fluor Hanford

P.O. Box 1000

Richland, Washington
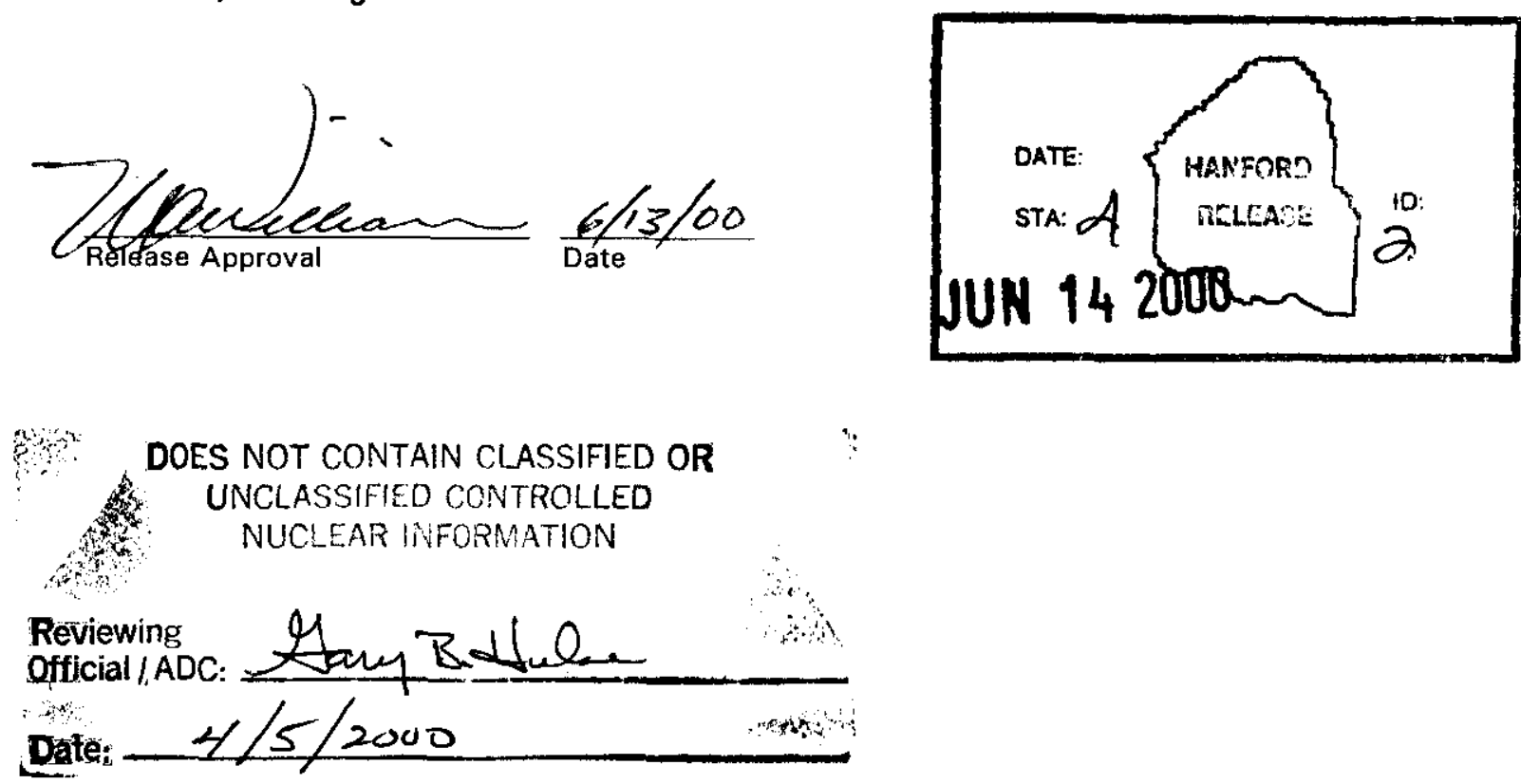


\section{LEGAL DISCLAIMER}

This report was prepared as an account of work sponsored by an agency of the United States Government. Neither the United States Government nor any agency thereof, nor any of their employees, nor any of their contractors, subcontractors or their employees, makes any warranty, express or implied, or assumes any legal liability or responsibility for the accuracy, completeness, or any third party's use or the results of such use of any information, apparatus, product, or process disclosed, or represents that its use would not infringe privately owned rights. Reference herein to any specific commercial product, process, or service by trade name, trademark, manufacturer, or otherwise, does not necessarily constitute or imply its endorsement, recommendation, or favoring by the United States Government or any agency thereof or its contractors or subcontractors. The views and opinions of authors expressed herein do not necessarily state or reflect those of the United States Government or any agency thereof.

This report has been reproduced from the best available copy. 
HNF-6175

Rev. 0

\section{ALARA Design Review for Resumption of PFP Cementation Process Project Activities}

\section{The Review}

Purpose $1-1$

Scope $1-1$

ALARA Review Methodology

$1-2$

Decision-Making Using an ALARA Decision Team ...

Attachment A

ALARA Design Review Checklist Cementation Process Project

Attachment B

Cementation Project Dose Summary, Timeline and Assumptions

Attachment C

Cementation Project ALARA Review Dose Estimate Table C-1 
HNF-6175

Revision 0

\section{ALARA Design Review for Resumption of PFP Cementation Process Project Activities}

\section{Purpose:}

The requirements for the performance of radiological design reviews are codified in 10CFR835, Occupational Radiation Protection. The basic requirements for the performance of ALARA design reviews are presented in the Hanford Site Radiological Control Manual (HSRCM). The HSRCM has established trigger levels requiring radiological reviews of non-routine or complex work activities. These requirements are implemented in site procedures HNF-PRO-1622 and 1623. HNF-PRO-1622

Radiological Design Review Process requires that "radiological design reviews [be performed] of new facilities and equipment and modifications of existing facilities and equipment". In addition, HNF-PRO-1623 Radiological Work Planning Process requires a formal ALARA Review for planned activities that are estimated to exceed 1 person-rem total Dose Equivalent (DE).

The purpose of this review is to validate that the original design for the PFP Cementation Process ensures that the principles of ALARA (As Low As Reasonably Achievable) were included in the original project design. That is, that the design and operation of existing Cementation Process equipment and processes allows for the minimization of personnel exposure in its operation, maintenance and decommissioning and that the generation of radioactive waste is kept to a minimum.

\section{Scope:}

The scope of this review is to re-validate and document ALARA design considerations for the successful resumption of the previously suspended PFP Cementation Process Project.

The PFP Cementation Process Project was originally started in the Fall of 1996. It was subsequently put on hold due to a self-imposed stand-down of operations by BWHC to correct observed plant performance deficiencies. The PFP Stabilization and Deactivation Project successfully restarted plutonium stabilization and packaging in January 1999.

The PFP Cementation Process was designed to immobilize Pu bearing Sand, Slag, and Crucible (SS\&C) and other residues (SNM of less than 30 wt-percent Pu) stored in the PFP vaults in cement. Stabilizing this material will facilitate disposal of the material as either TRU/M or TRU waste and reduce worker exposure. This project is one of several modifications being undertaken by PFP Solutions/Residues Stabilization Project to stabilize Plutonium solutions and solids in support of the PFP Integrated Project Management Plan (IPMP). Plutonium currently stored at PFP must be stabilized for long-term storage and eventual shipment to the Savannah River Site for final disposition $(>30 \% \mathrm{Pu})$ or packaged for long term storage and eventual shipment. Solid waste 
HNF-6175

Revision 0

generated by these processes will be sent to WIPP (TRU/M or TRU) or to Low Level Waste by the onsite management interface.

The material to be cemented (i.e. SS\&C) will be removed from the vaults, assayed via Non-Destructive Analysis (NDA) and transported to an existing Glove Box, HA-20MB, for cementation. Cemented material, after curing, will be sealed out of the Glove Box or it's associated conveyor. The cemented cans will be put into waste drums containing a Pipe Overpack Container (POC). The TRU waste drums will be stored for later shipment to the Waste Isolation Pilot Project (WIPP).

This ALARA design review is limited to those operational and maintenance activities conducted during the removal of the SS\&C material from the vaults, transport to and from NDA, transport to the Glove Box, cementation activities in the Glove Box, and final packaging and transport to the onsite storage location. Other residues, Ash and Oxides will be covered under a separate review once further information is available.

\section{ALARA Review Methodology}

The radiological design review process at Hanford and PFP are conducted at two levels:

(1) Minor modifications of existing facilities, and

(2) Major modifications of existing facilities or new facilities.

Minor modifications are those changes that are not expected to result in significant personnel dose during installation, operation and maintenance. The review of such activities is normally conducted as part of the routine radiological work planning process per HNF-PRO-1623 (Reference 2).

Major modifications to existing facilities are defined as "A physical change to a structure, set of structures or system(s) that could result in either a change in collective radiation exposure due to installation, maintenance and operations of 1 person-rem TEDE [Total Effective Dose Equivalent] or greater or a change in collective extremity dose of 10 person-rem or greater over the life of the project." The review of such changes requires a structured radiological design review process per HNF-PRO-1621, 1622 and 1623 (References 2,3 and 4)

Furthermore, a major modification is required to have a radiological engineer as a member of the design team if the modification meets any of the following criteria:

- The whole body collective dose for installation, maintenance and operation of the modification might reasonably be expected to exceed 5 person-rem over the life of the project.

- The collective extremity dose for installation might reasonably be expected to exceed 50 rem over the life of the modification. 
HNF-6175

Revision 0

- The modification meets the criteria for a radiological design review, and the radiological control manager feels that the modification is sufficiently complex or risky to warrant having a radiological engineer on the design team.

Based on current program requirements, the PFP Cementation Process Project would have been classified as a major modification that required a radiological engineer on its design team based on both its potential exposure to PFP personnel and the significance and uniqueness of the process to PFP. At the time of the original project implementation, B\&W Hanford Company assigned a member of the PFP Radiological Engineering staff to this project. Once it was determined that a project restart was planned and the project designated as a former major modification, thus establishing the need for a radiological design review, a new PFP Radiological Engineer was assigned to the project. A contract radiological engineer was later assigned to support this individual.

Review of current site and PFP ALARA Design Requirements requires that a choice must be made for which ALARA Decision-Making Methods will be used. As described in HNF-PRO-1621, ALARA Decision-Making Methods, there are currently three methods approved for use at Hanford:

(1) Standard Decision Making Method

(2) Decision-Making Using Cost-Benefit Analysis

(3) Decision-Making Using an ALARA Decision Team

Of the three available methods, method three (3) was chosen as the most appropriate method utilized during the original project design. Furthermore, based on the review of past data, it appears to be equally applicable today, and has thus been utilized as part of the restart project.

"This method is appropriate at the stage of design or work planning where many small decisions about the design or task would likely make a significant affect on the exposure due to installation, maintenance and operations, but where the use of other decision making techniques would be prohibitively difficult because of the number of relatively small decisions to be made."

Although it would not be accurate to characterize the decision making process for the cementation project as being "prohibitively difficult" to analyze due to the large number of "relatively small decisions to be made", it is entirely appropriate to characterize this project as one whose "whole is greater than the sum of its parts". That is, the design effort is focused on making the glovebox and cementation process work together to ensure a more radiologically acceptable product. Such an effort is not best characterized/evaluated by cost-benefit analysis alone (although small decisions may be driven by ALARA cost-benefit considerations).

Since the DNFSB 94-1 Implementation Plan had identified cementation as the process of choice for SS\&C, and because of the nature of this project (i.e., ensuring that the 
HNF-6175

Revision 0

glovebox modifications and cementation process is ALARA, rather than determining which glovebox design and process is more ALARA), evaluation under the ALARA Decision Team process appears appropriate.

\section{Decision-Making Using an ALARA Decision Team}

HNF-PRO-1622, Radiological Design Review Process, outlines the 12 basic steps to be taken for the performance of a radiological design review (Figure 1). Backup documentation (such as meeting minutes, design drawings, memorandums, and such) is contained in the FHI cementation project file (which is maintained according to the FHI record retention process). This information shall stand as documentation for the performance of the individual steps required for the radiological design review process (or to show how the intent of each step was followed).

For the sake of brevity, and to eliminate redundancy, no copies of these documents have been attached to this radiological design review package (unless these documents are germane to the understanding of this ALARA design review package). However, a brief synopsis is provided herein to demonstrate how the intent of each step was met.

\section{Initial Radiological Input to Early Project Conception}

During the original phases of the Cementation Process Project, the PFP Radiological Control Manager worked with the FHI Design Decision Authority by assigning a member of his radiological engineering staff to work with the design team (comprised of engineers, designers, operators, and managers from B\&W Hanford Company and FHI. The radiological engineer was an integral part of the design team and participated actively. A review of the documentation and discussions with design team members indicate that the radiological engineer was involved intimately in major decisions. In addition, the Design Authority ensured that the budget contained resources necessary to cover the expected costs of the radiological design review and any preliminary ALARA controls identified in the System Design Description (SDD) or in conceptual design meetings. These functions are currently being performed through the Project Cognizant Engineer and the assigned PFP Radiological Engineer.

\section{Design Review Process and Schedule}

The former FHI Design Authority and the current Cognizant Engineer maintains a project schedule, which delineates the key steps in the ALARA design review process. Although this schedule is not driven primarily by the design review process, the schedule none-theless accounts for major design review steps (for example, activity timelines and engineering controls evaluation). As required by HNF-PRO-1622, a "Basic Design Review Checklist" was completed for the Cementation Process and is provided as Attachment 1 to this document. 
HNF-6175

Revision 0

$\underline{\text { Functions and requirements }}$

A System Design Description (SDD) for the Cementation Process Project was issued by PFP Process Engineering (Ref. 5). The purpose of this document is to address the specific scope and location of the project, provide its justification, delineate the integration of the project, describe the equipment and the processes involved, provide equipment performance characteristics and criteria, and outline the design criteria to be used for components and systems. This document either provides the criteria itself or directs the reader with specific references.

The SDD received a formal review by the PFP Radiological Engineering staff as part of the formal document review and approval process. The Cognizant Engineer is currently revising this project document. No significant radiological issues were outstanding at the time of its finalization.

\section{Process Flow Document or Other Description of Process}

In addition to the information contained in the SDD, other documents exist that pertain to process descriptions. Two such documents include the Process Flow Document (PFD) for the Cementation Process and the Operating Specification Document (OSD) for the Cementation process. Based on these two documents, the SDD and discussions with representatives of PFP Projects, PFP Solution/Residues Stabilization Operations and PFP Engineering, the radiological engineer developed a process timeline, Attachment 2, Cementation Project Dose Summary, Timeline and Assumptions. This timeline was then used to determine the radiological exposure and dose expected from the operation of the Cementation glove box, Attachment 3, ALARA Design Review Dose Estimate Table.

Expected activities, concentrations, dose rates and other assumptions were derived from various documents (See references 6-9) and discussions with project personnel.

\section{Design Specifications (or Criteria)}

Conceptual/Preliminary Design

Design drawings to be used in the modification of the original glove box and process equipment were reviewed by the original Radiological Engineer. Several recommendations were made by the radiological engineer on the glovebox design and process operation. Design considerations were incorporated into the modification specification for the glovebox. These recommendations were made by formal documentation between the radiological engineer and the design engineers as part of the ALARA Assessment for the Cementation Process Project (Ref. 6).

\section{Final Design}

Final design specifications were incorporated into the SDD (Ref 5). 
HNF-6175

Revision 0

\section{Preparation of Dose Estimates}

A design criterion of $1,000 \mathrm{mrem} / \mathrm{yr}$ (TEDE) was utilized when evaluating engineering controls for work at/in the glovebox. This is consistent with 10CFR 835 and HSRCM requirements.

Dose estimates were performed using the information derived from the process timeline, available survey documentation, discussions with experienced operations and radiological controls personnel and source dose rate calculations provided by References 6,7 and 8. A Microsoft Excel spreadsheet was developed to easily evaluate the impact on worker dose from changes in Pu concentration, source dose rates, number of batches processed, and process times (Attachment 3 ).

Based on using the most likely scenario of processing 2 batches per shift of containers having 50-60 g of Pu material, assuming a shift complement of five operators per shift for two shifts, and a work off rate of two batches per shift, an operator would be likely to receive approximately $570 \mathrm{mrem} / \mathrm{year}$ above ambient background levels. Taking ambient background levels into consideration for process areas, an operator would be likely to receive approximately $850 \mathrm{mrem} / \mathrm{yr}$.

NOTE: The $850 \mathrm{mrem} / \mathrm{year}$ is based solely on the operator's incremental exposure received while assigned to the Cementation project. Any additional exposure the operator receives while assigned to other projects during the year has not been included here.

\section{Re-Start Testing}

The Project Cognizant Engineer is developing a procedure to outline the functional testing required of the glovebox and process equipment. This test will be reviewed by PFP radiological engineering prior to its implementation.

This procedure will include steps to ensure that assumptions made in the radiological design review process were accurate. Such radiological steps will include, but not be limited to:

(1) time - motion reviews

(2) gamma and neutron dose rate measurements

(3) effectiveness of engineering controls 
HNF-6175

Revision 0

\section{Post Re-Start - Review of Effectiveness}

HNF-PRO-1622 states that "after one year of operation of the equipment for which a design was done, the Radiological Control Manager shall ensure that the effectiveness of the design radiological measures are reviewed". However, since this project is likely to have less than a 4-year life, waiting one year for post construction review of effectiveness is not acceptable.

At the end of 6 months of full time operations (after the initial "break-in period"), the PFP Radiological Engineering staff will provide a review of the effectiveness of ALARA design parameters for equipment and process operations. This review should entail the following parameters:

(1) A review of radiological conditions, including:

a- Confirmatory surveys of actual dose rates, contamination levels and airborne contamination levels. This should include a review of routine survey data collected during operations.

b- Comparison of actual to expected dose rates and contamination levels.

c- Evaluation of individual and collective dose based on operational data.

d- Explanation of significant differences.

(2) A discussion of any unexpected facility and/or equipment layout problems, or any unexpected construction, maintenance or operational problems with radiological consequences. This can be determined by

a- Evaluating the effectiveness of glovebox and process equipment

b- Reviewing process operations to determine if physical and/or procedural modifications can be made to improve worker efficiency and hence lower exposure

(3) Recommendations for future equipment design and operations

Note: Due to the nature of this process, it is not necessary to suspend operations while performing this review.

\section{Individual and Area Monitoring}

During routine operations, individual and area monitoring will be used to demonstrate that the basic radiation dose limits are not exceeded and that the exposure levels are ALARA. The existing operational ALARA program and radiation control program will be used to implement this process. 
HNF-6175

Revision 0

\section{ALARA Design Considerations}

During the design and operational preparations for the original cementation process run, ALARA considerations were recommended and instituted to decrease the expected dose. A summary of these actions are provided below:

Minimize Operator Time at Glove box in Gloves

- Feed with auger instead of hand feeding

- Equipment switches outside the glove box

- Valves outside glove box, where possible

- Remote temperature sensors

- Mixing by machine versus hand

- Sphincter port installed for product can and cement insertion

- Commercial can opener to open cans versus a hand opener

Optimize Operator Dose

- Equipment grouped on side of glove box with lowest background dose contribution

- Shielding provided on most used side of glove box

- Water shields provided to reduce background dose from HA-23S Glove box

- Cleanout of the HA-20MB Glove box and adjacent glove boxes to improve background levels

Process Controls

- Higher dose items sent to Los Alamos for reprocessing

- Blend Plan limits items for cementing to $<60 \mathrm{~g}$ Pu per item.

- Maximum batch sizes used, where possible

- Use of larger slip lid can to cement material and reduce total number of containers and associated dose

\section{Current Recommendations}

As a result of this ALARA review, the following ALARA recommendations are provided to further promote the ALARA philosophy and reduce personnel dose.

1) Consideration should be given to using additional engineering controls to minimize the spread of contamination and 
HNF-6175

Revision 0

generation of airborne radioactivity during seal outs from the conveyor and during the opening of the lard cans.

- Add a seal in port on the conveyer HA-28, east of Glovebox HA-20MB. Build a containment structure at this location to use for opening the lard cans and sealing in the individual containers. This containment can also be used to seal out cemented billets and load them into the pipe overpack containers.

2) Consideration should be given to further reducing background radiation levels around the Cementation Glove box. Background radiation accounts for more than a third of the dose being picked up by project personnel. Consideration should be given to eliminating or reducing background radiation levels through

- Adding additional shielding to reduce the impact from radiation scatter or shine from near by equipment,

- Flushing /decontamination of lines and ventilation ducts to reduce contribution to background levels, and

- Conducting seal ins and seal outs in lower background areas and not near the glove box.

3) Consideration should be given to further reducing task cycles by maximizing and consolidating materials during transport, elimination of multiple redundant activities (i.e. NDA) and pursuing improvements in work processes and special tooling to reduce time spent in radiation fields.

4) Consideration should be given to promoting the consistent application and use of lead aprons and gloves for all process tasks to help reduce chronic exposure from low energy $\mathrm{x}$-rays.

5) Consideration should be given to improving the plants ability to track, trend and alert personnel of radiation fields and dose they are being exposed to during project work. The plant should investigate the use of improved electronic dosimetry to provide feed back to workers (i.e. chirping) and data to decision makers so they can make informed decisions on the best utilization of worker dose in accomplishing plant priorities on a real time basis. 
HNF-6175

Revision 0

6) Consideration should be given to finalizing the design and construction of new, shielded transfer wagons to further reduce personnel dose during material transport.

References:

1) 10CFR835, Occupational Radiation Protection

2) HNF-PRO-1623, Radiological Work Planning Process

3) HNF-PRO-1622, Radiological Design Review Process

4) HNF-PRO-1621, ALARA Decision Making Methods

5) System Design Description for the Cementation Process project, HNF-SD-CP-SDD-020

6) ALARA Assessment for HA-20MB Cementation Process, Internal Memo 15530-96-MWG-099, 9/96

7) PFP Stabilization Dose Equivalent Estimate, Mel Chew, 1995

8) Analysis of Immobilization Alternatives, EIS-0244-F

9) PFP Survey Data for Vaults and Cementation Glove Box Background, 2/00

Figures:

1) Schematic Representation of the Radiological Design Review Process

Attachments:

1) ALARA Design Review Checklist, Cementation Project

2) Cementation Project Dose Summary, Timeline and Assumptions

3) Cementation Project ALARA Design Review Dose Estimate Table 
HNF-6175

Revision 0

Figure 1

Schematic Representation of the Radiological Design Review Process for Major Modifications of Existing Facilities and New Facilities

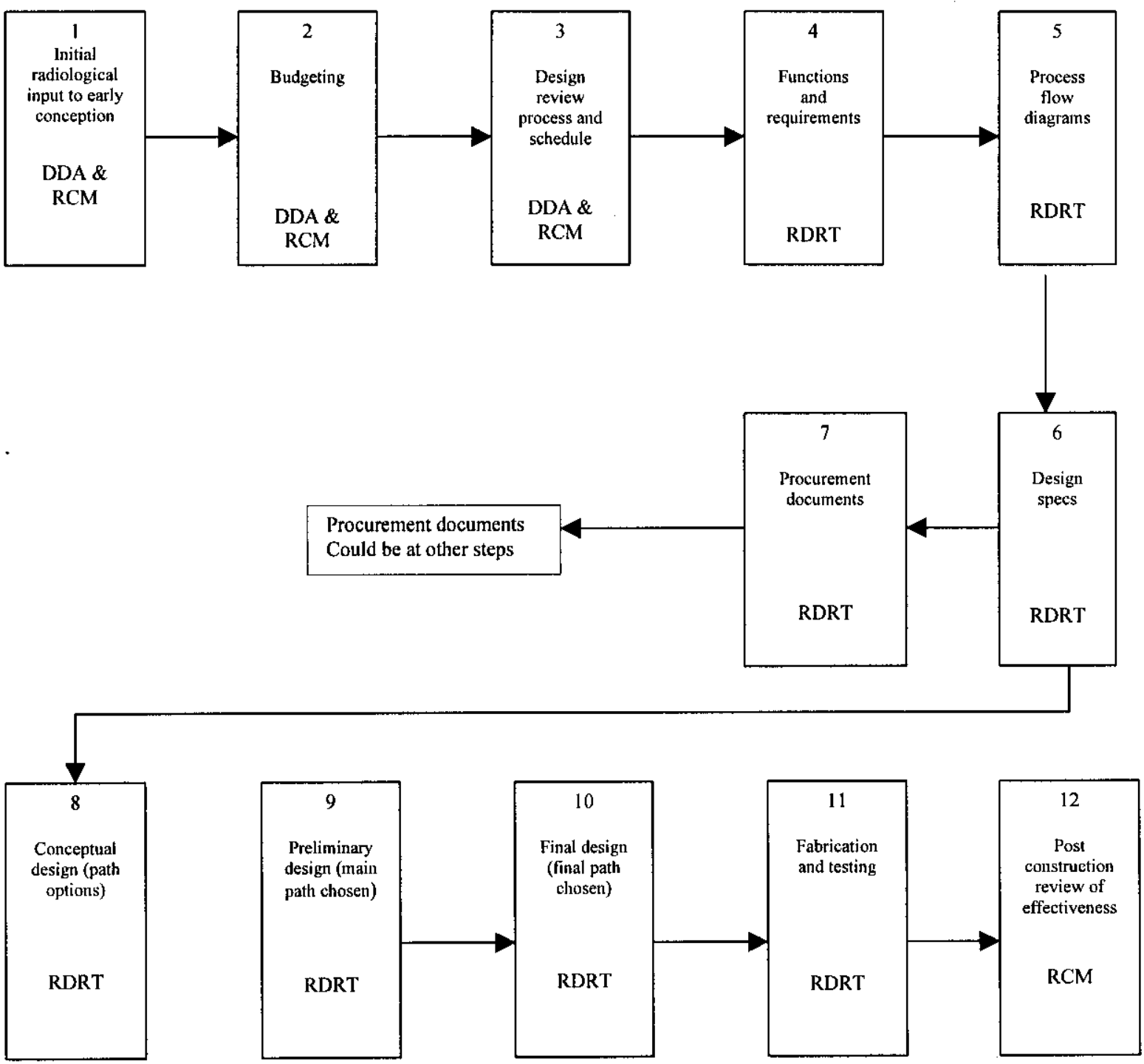

DDA $=$ Design Decision Authority

RCM $=$ Radiological Control Manager

RDRT $=$ Radiological Design Review Team

Note: For a given project, the exact steps and sequence of steps may vary, but the intent will be preserved 


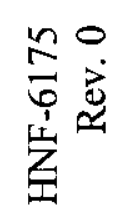

总乎

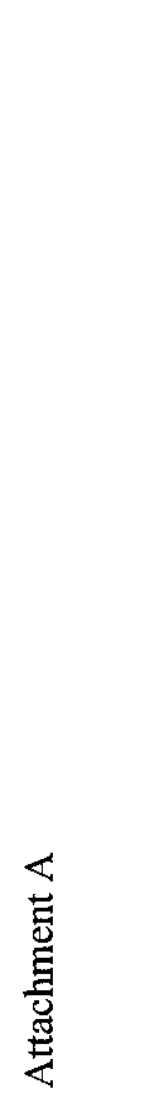

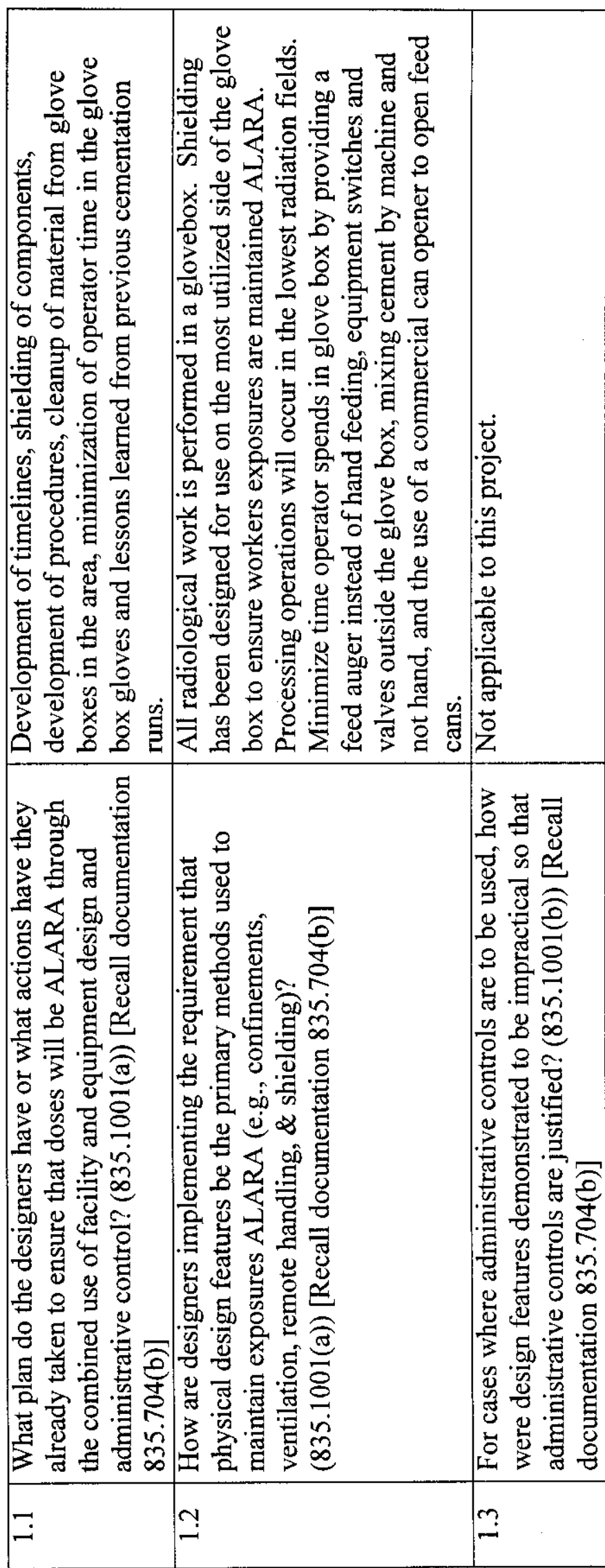




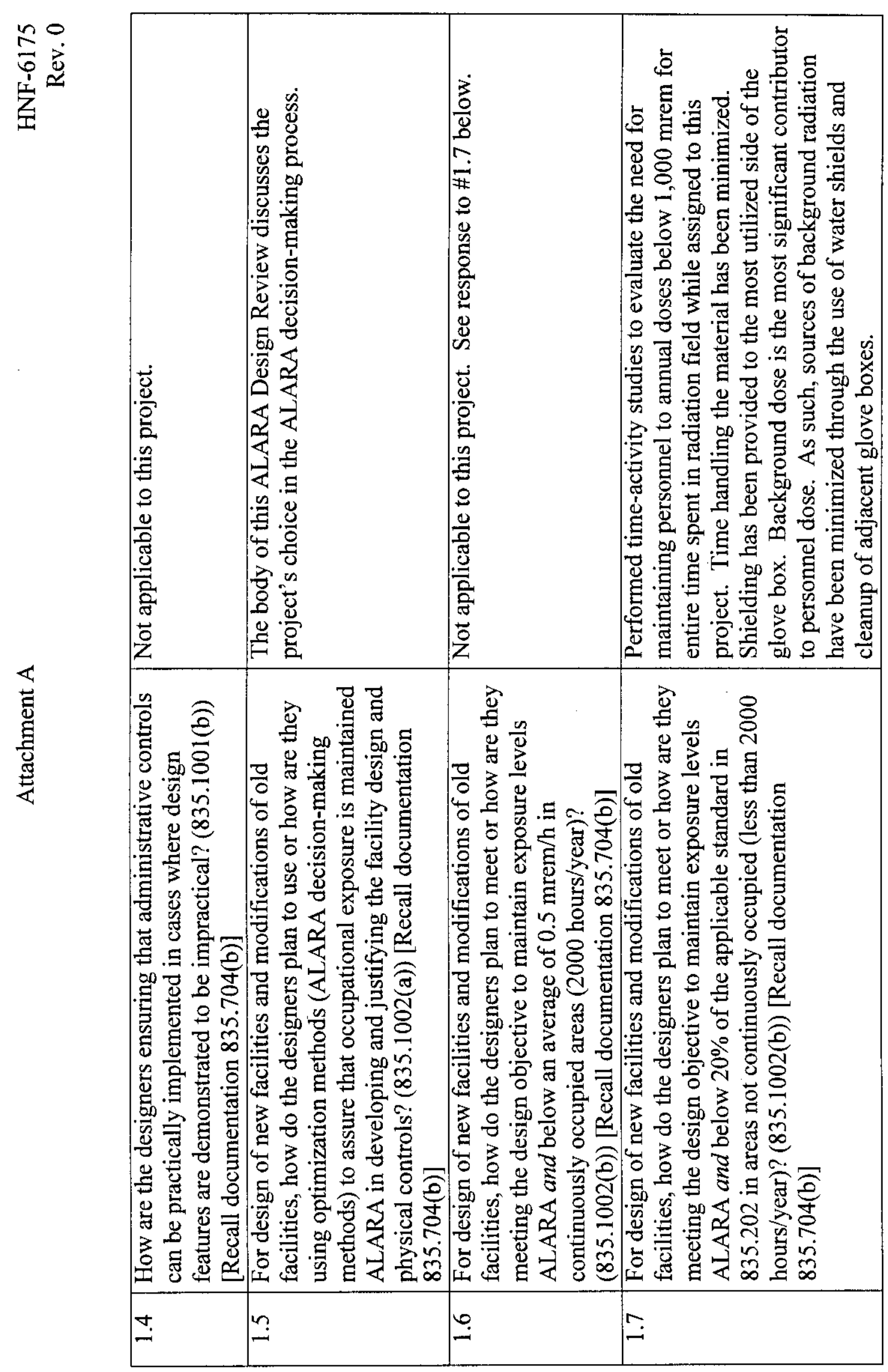

4 


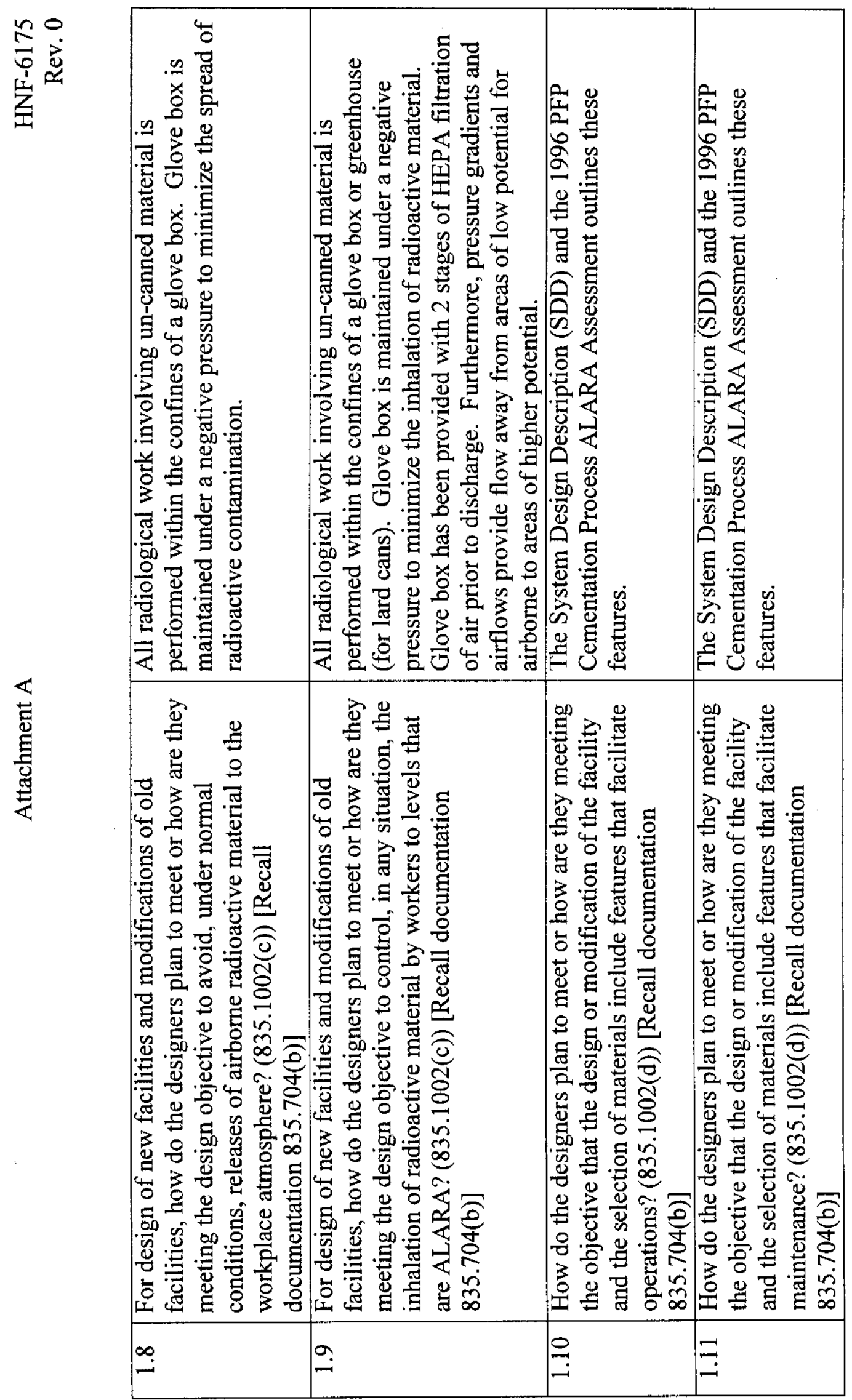



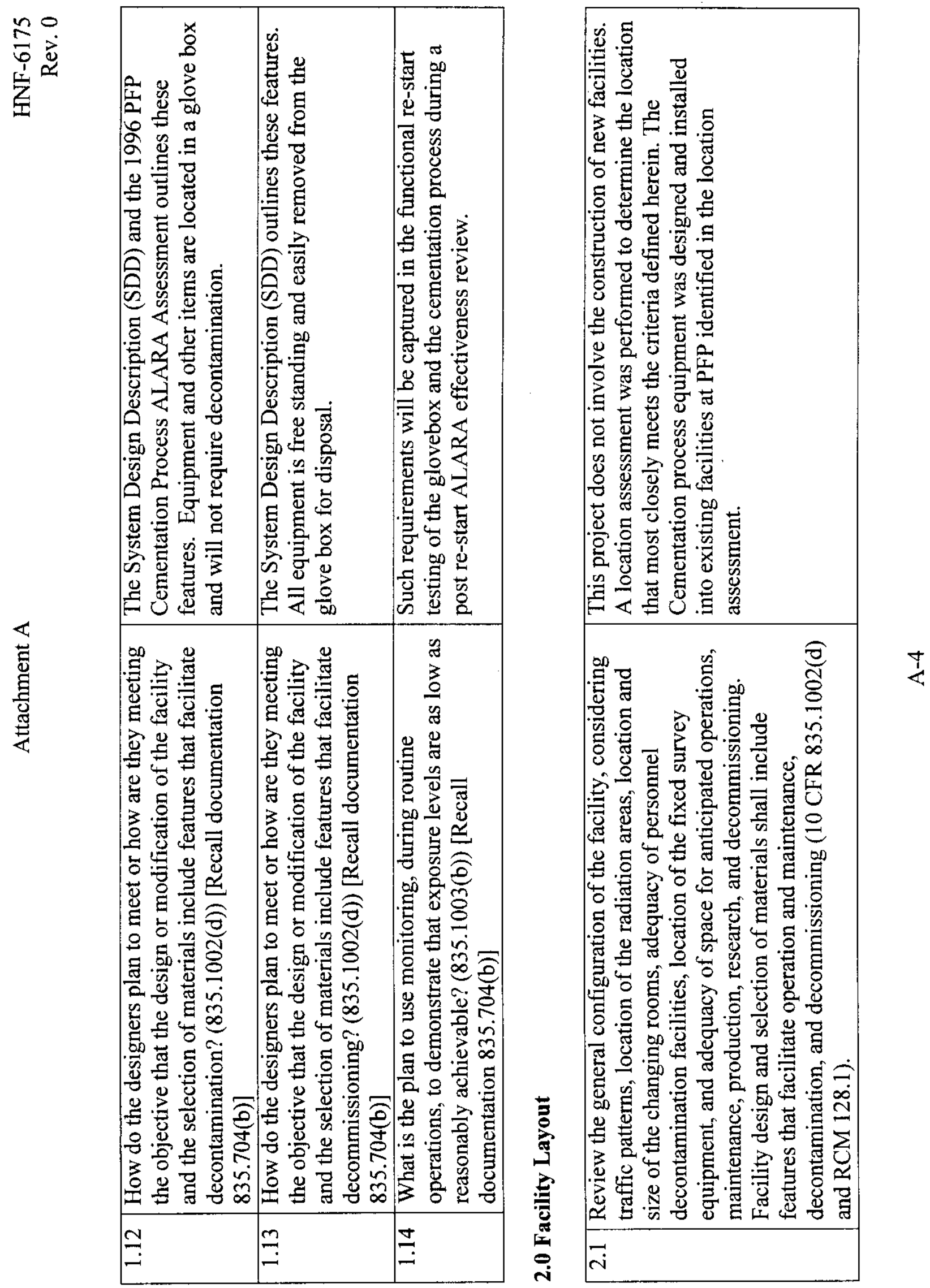


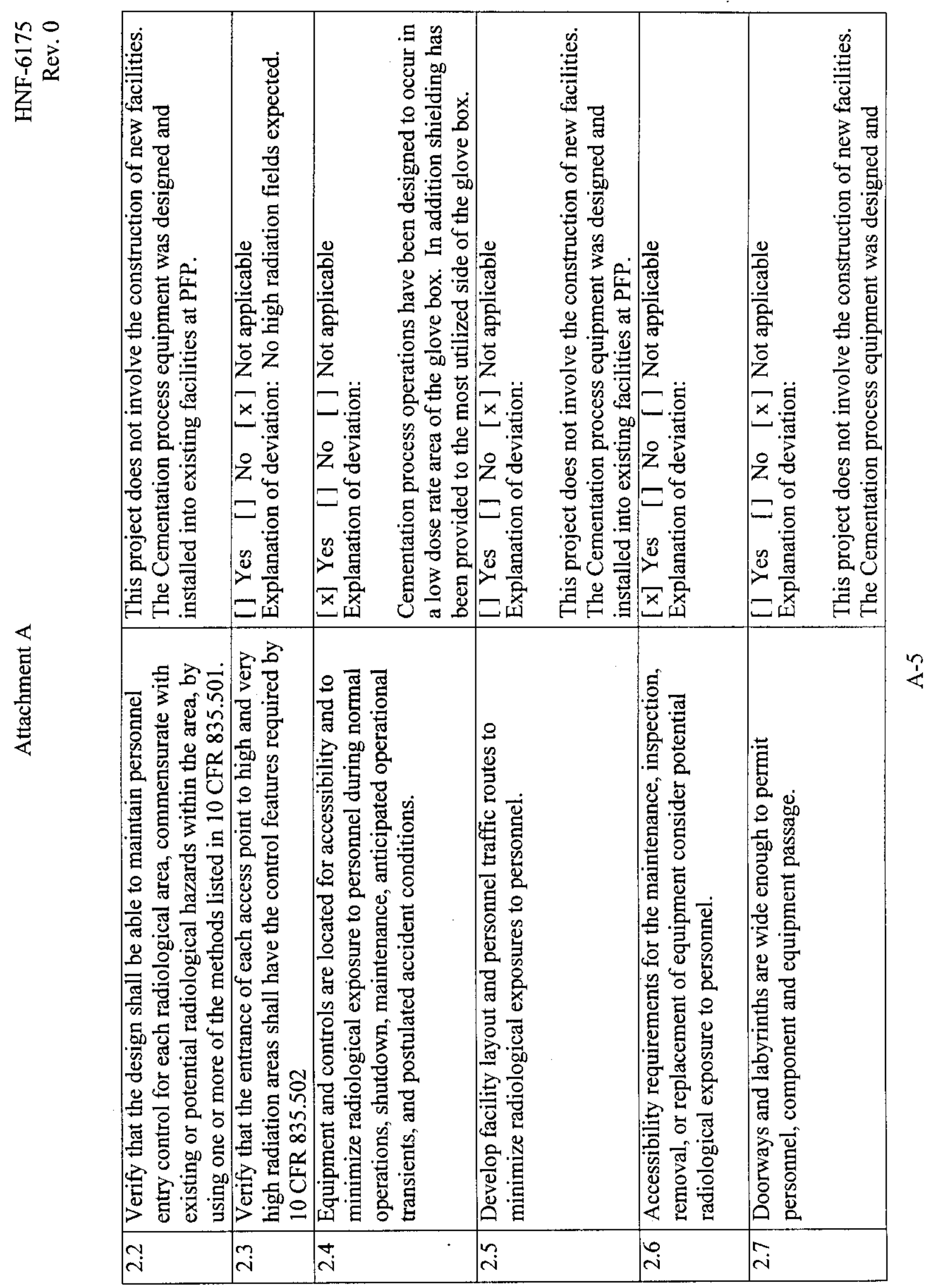




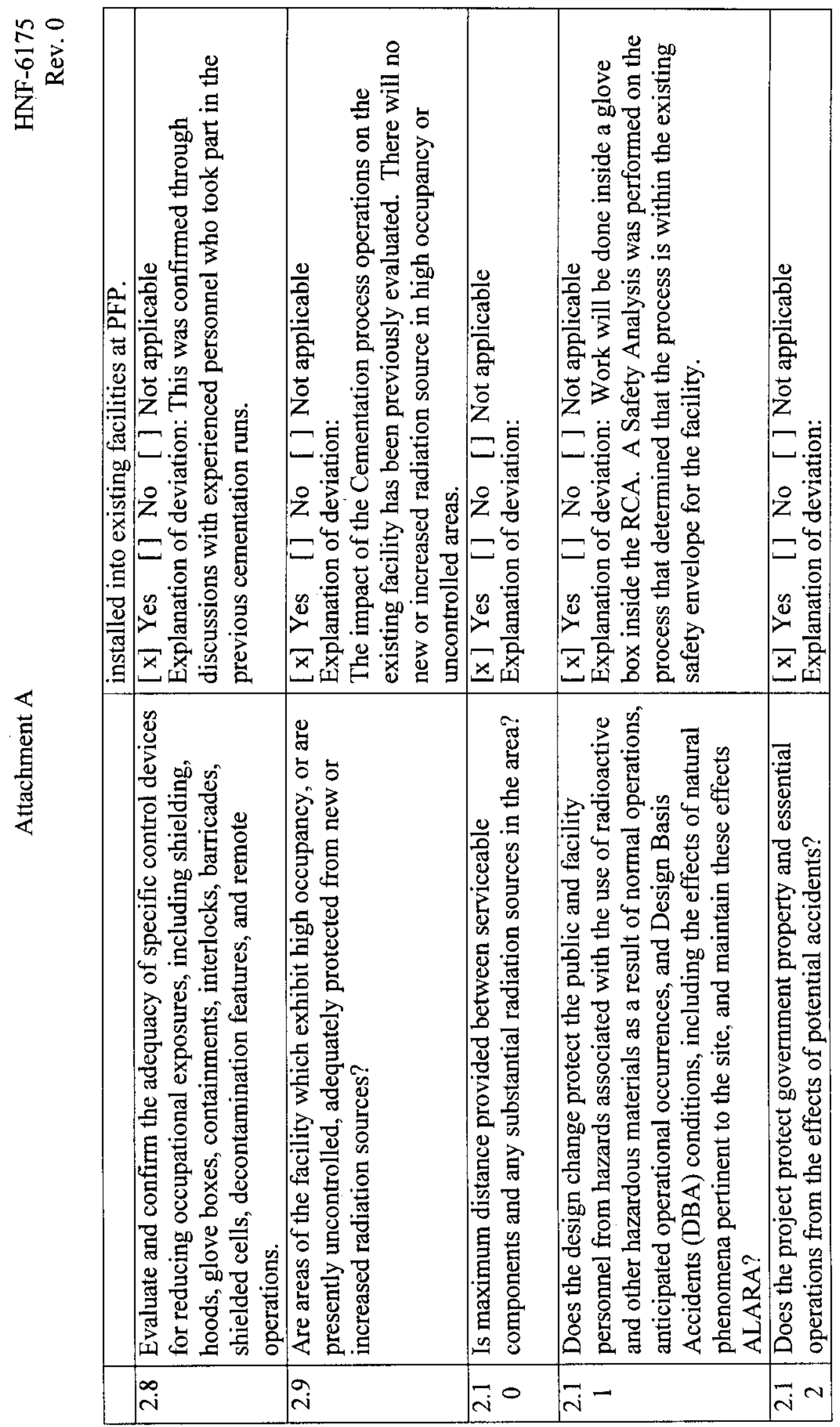



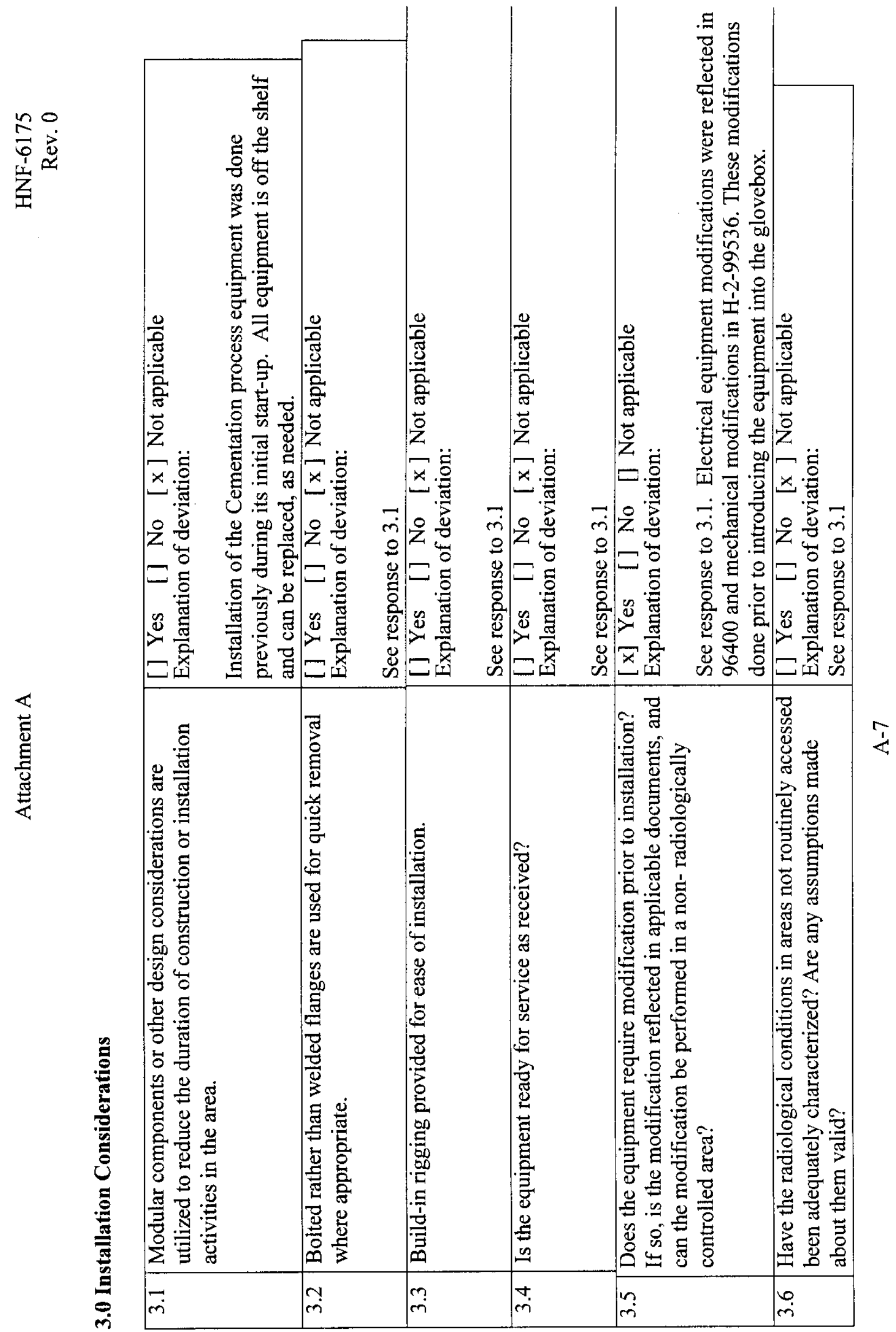

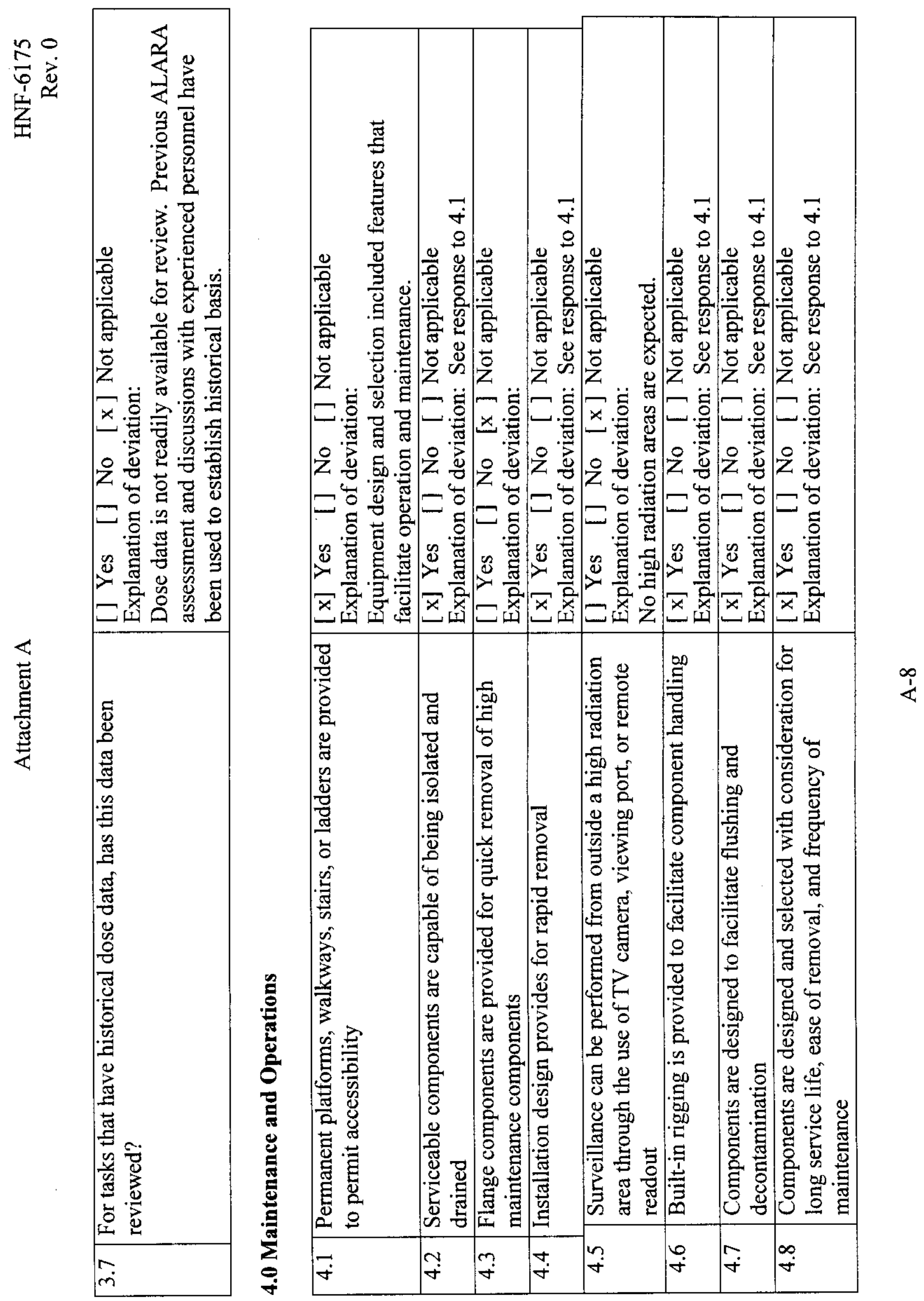

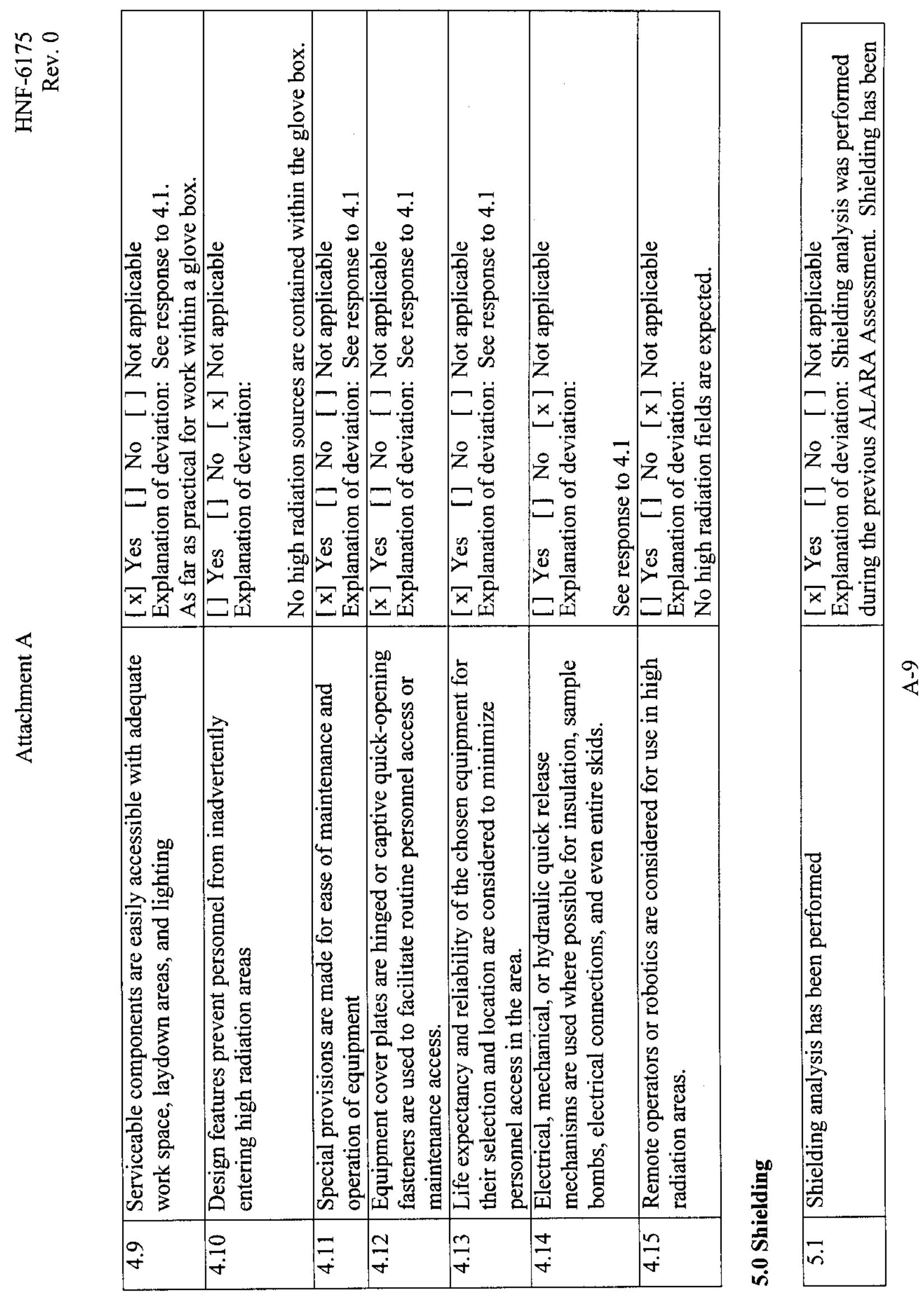


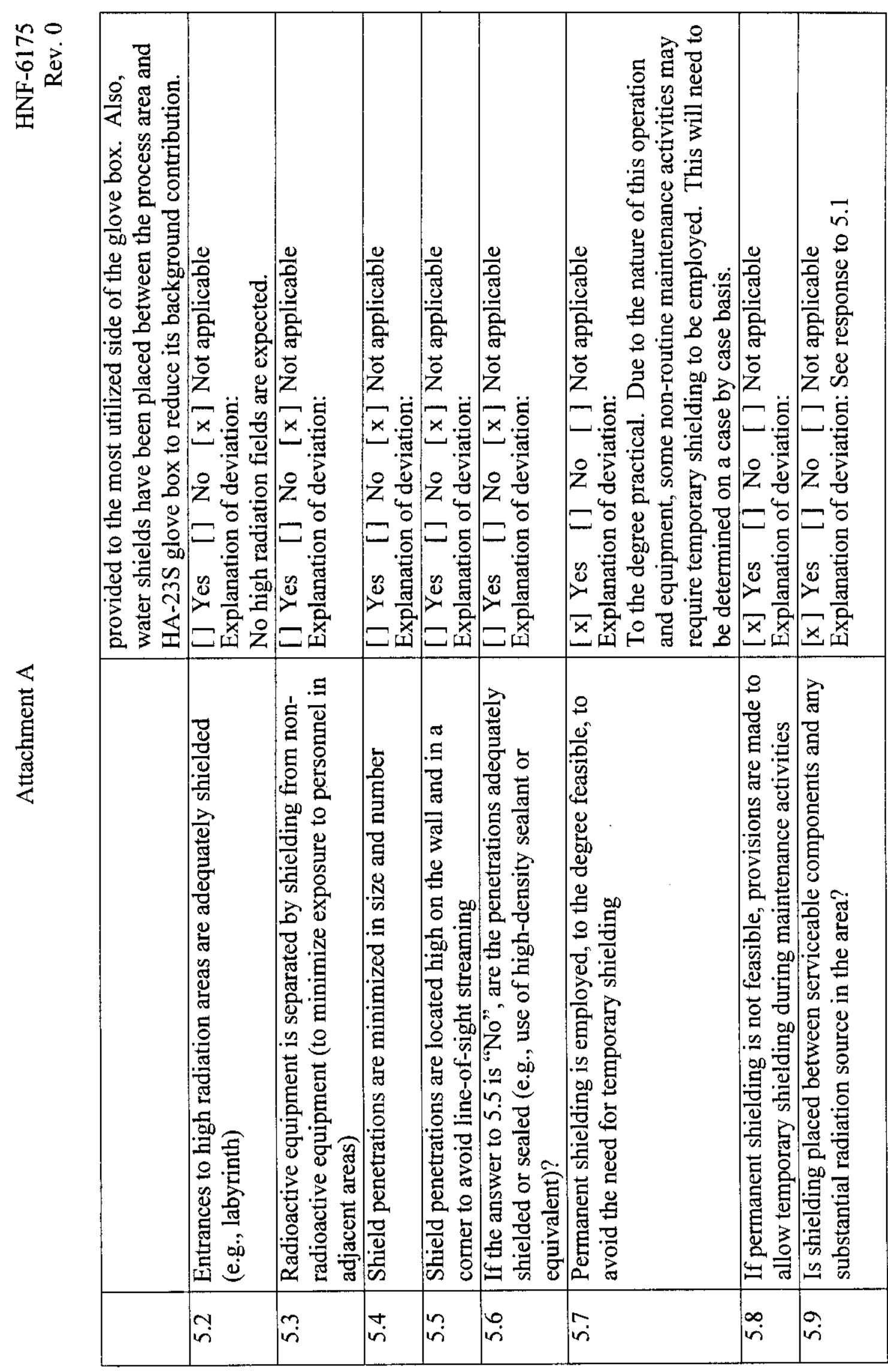



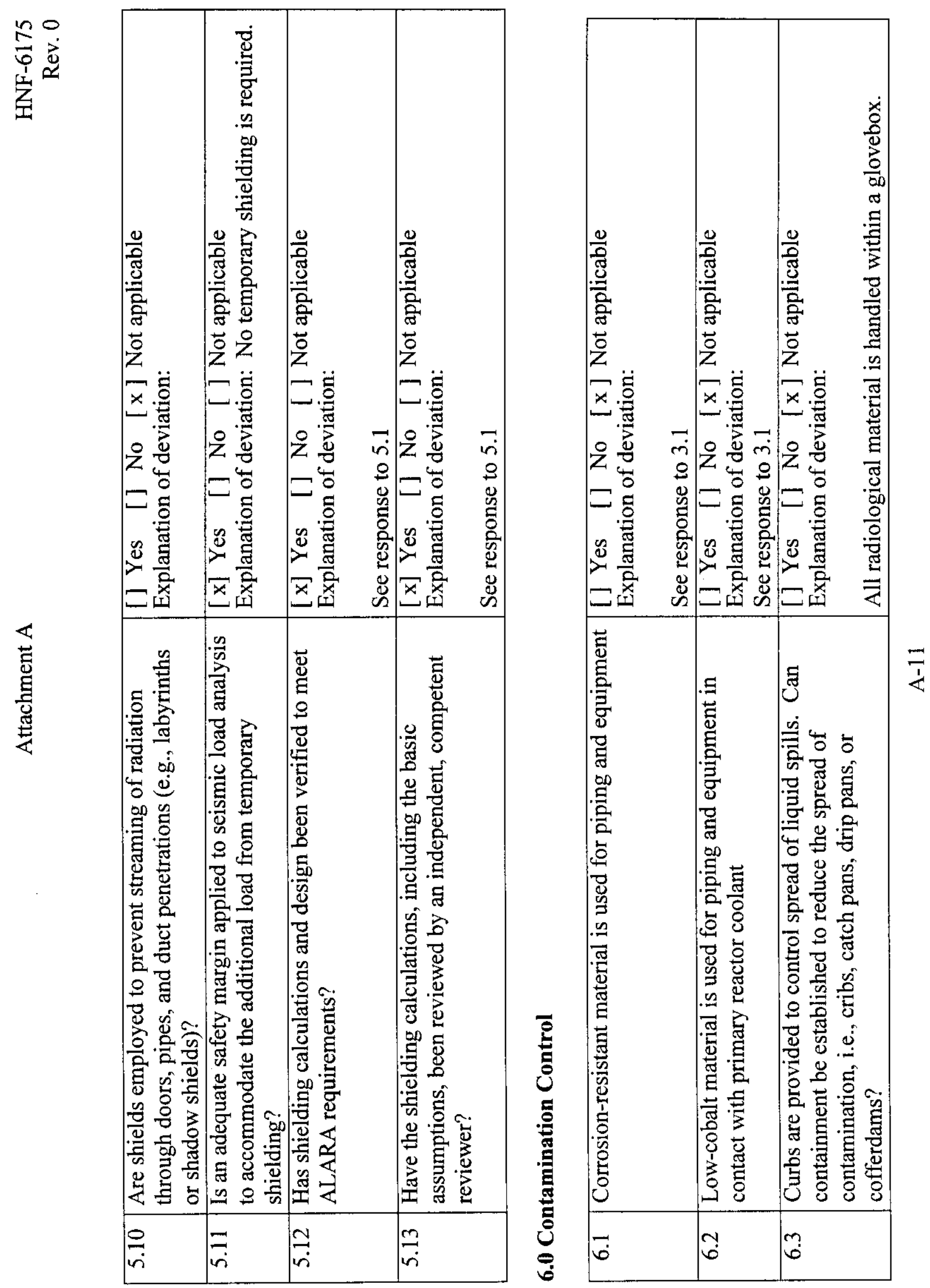


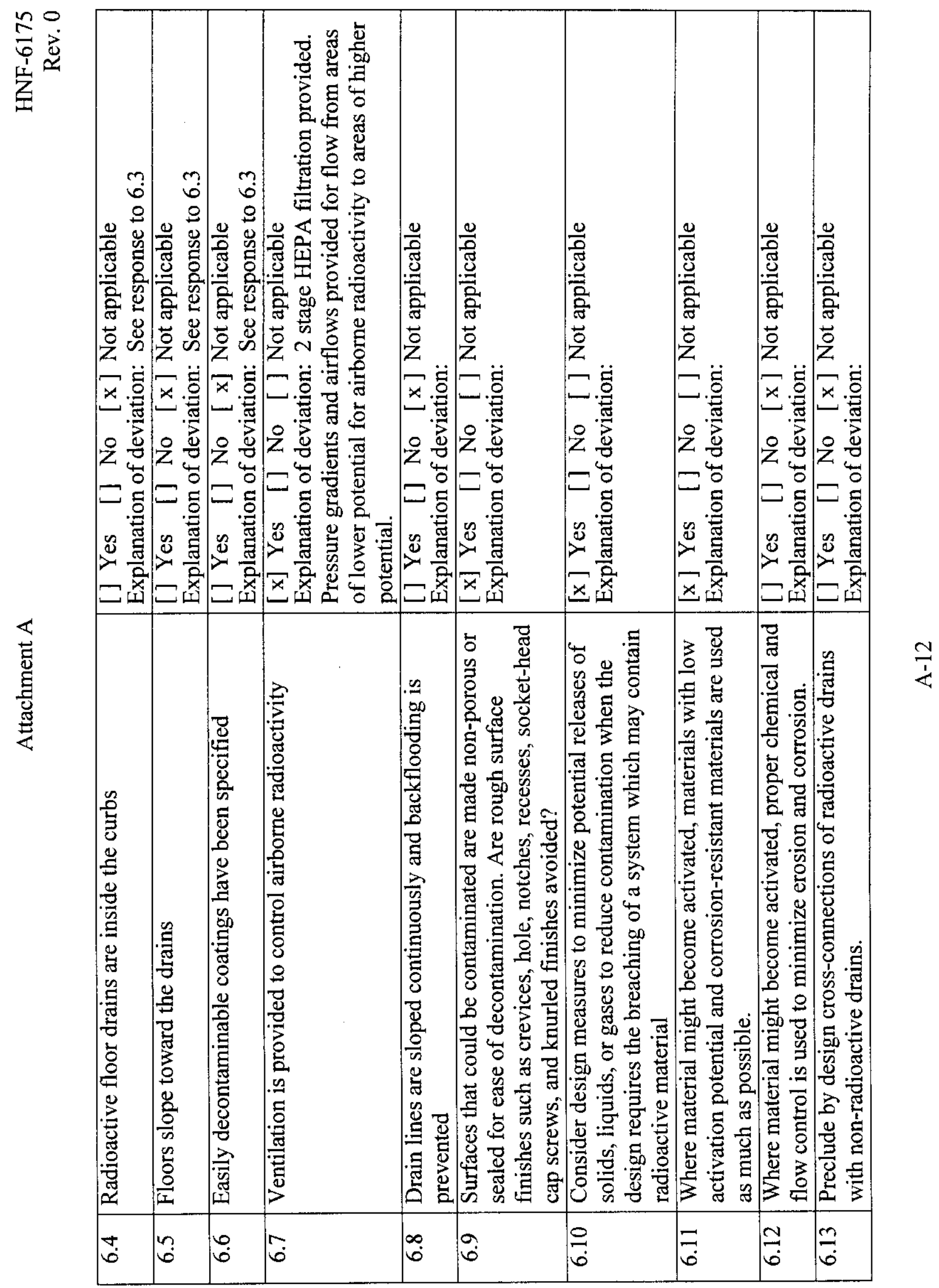



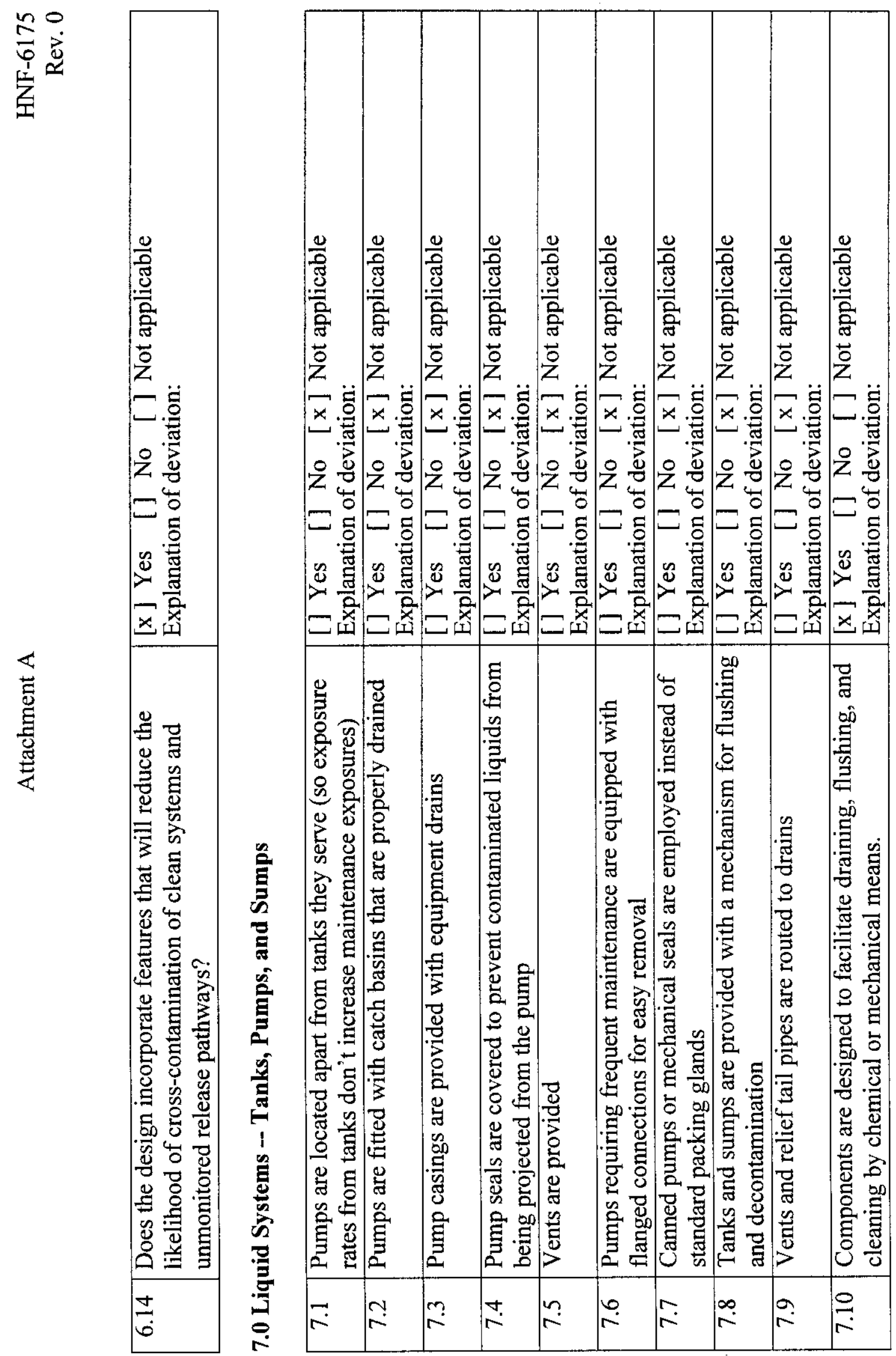

$\frac{m}{4}$ 

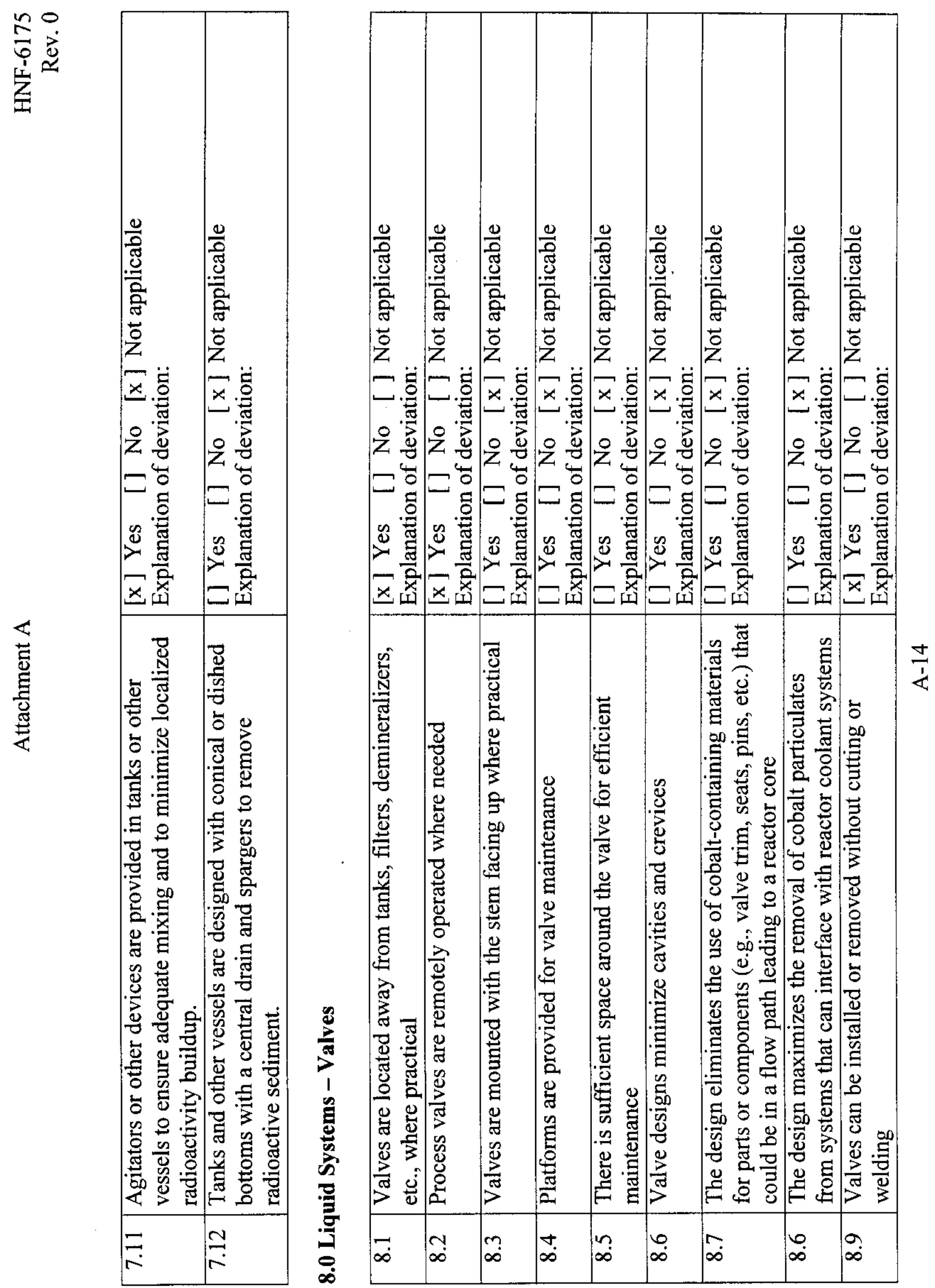

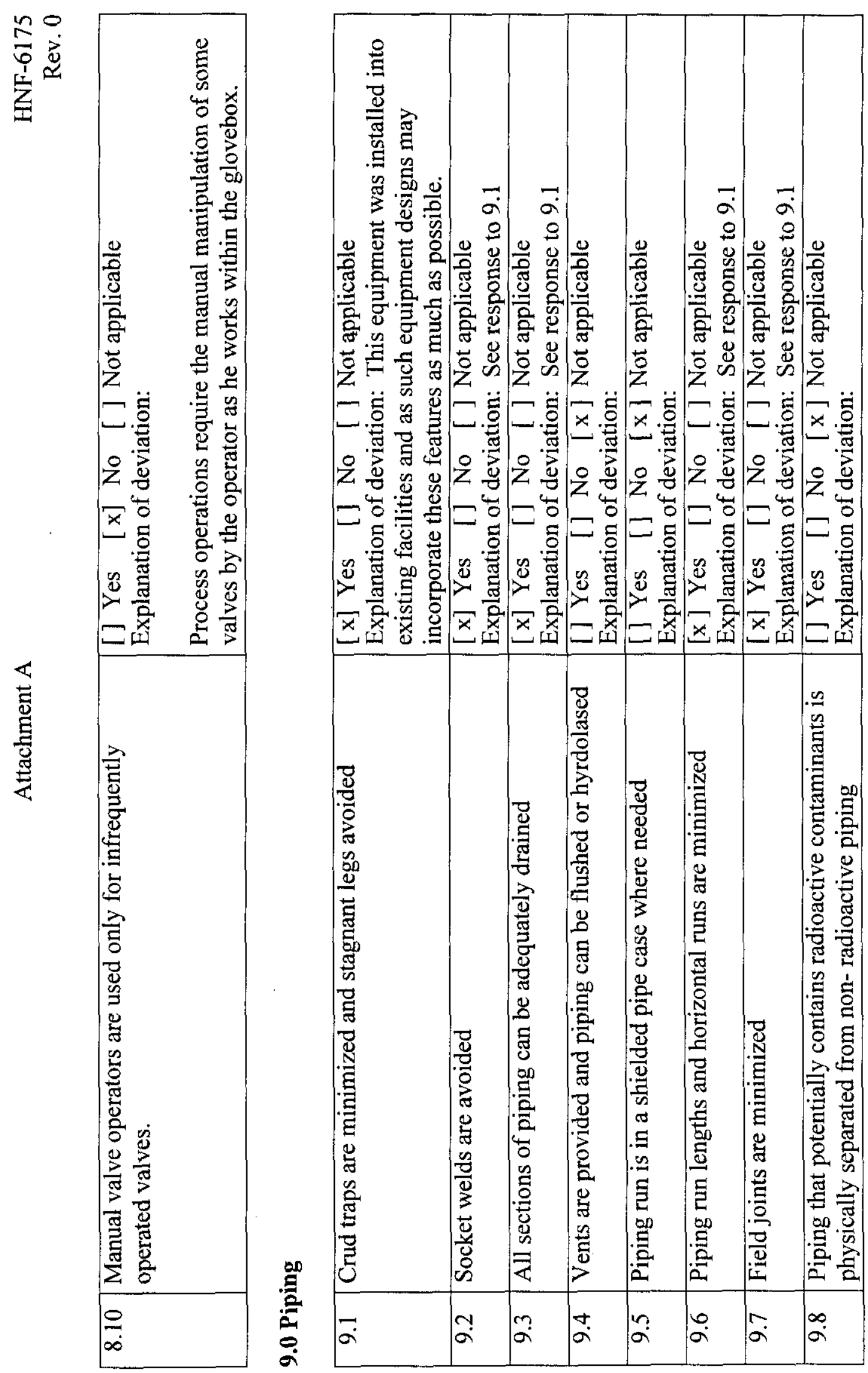

$\frac{n}{4}$ 

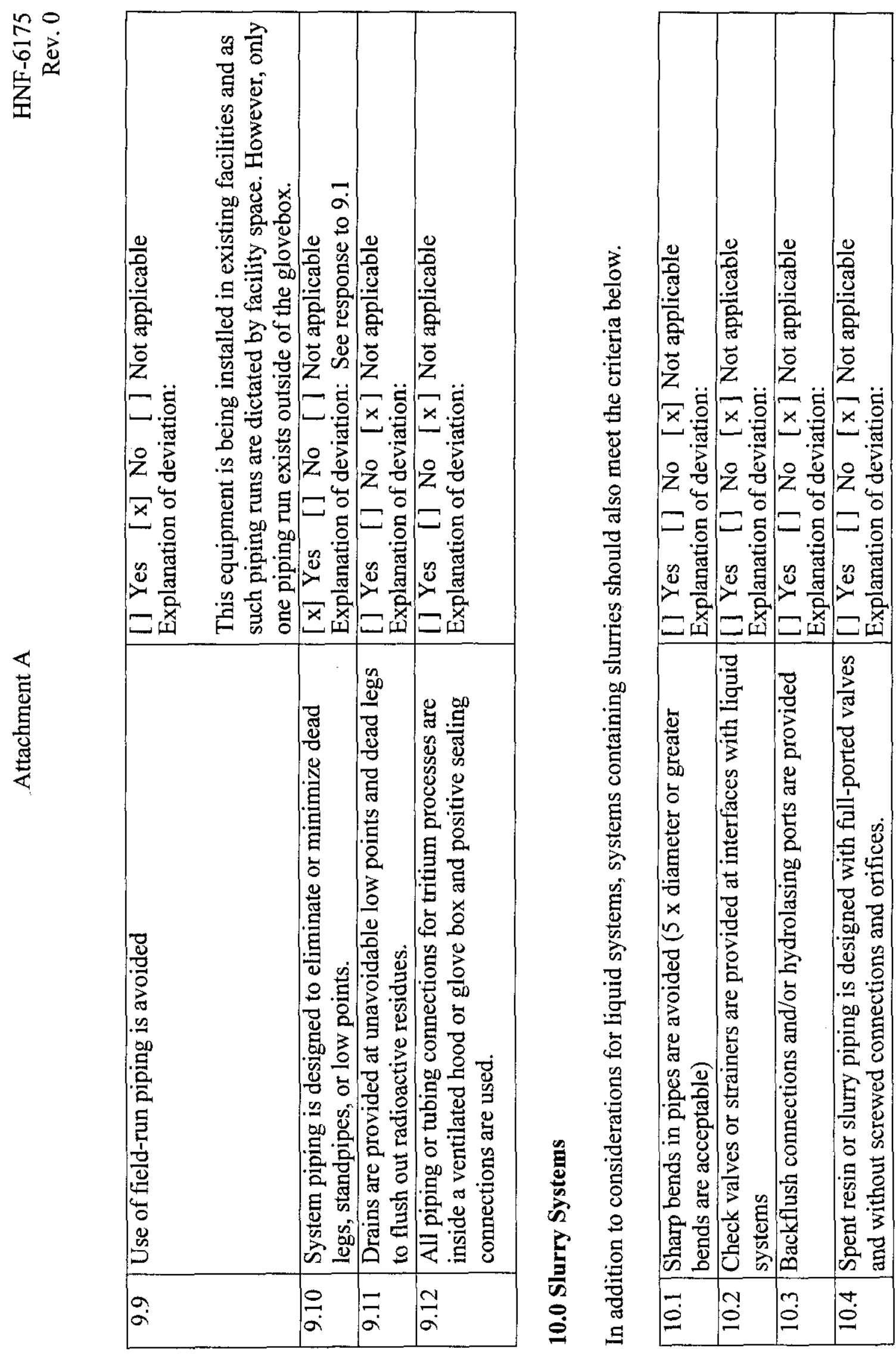

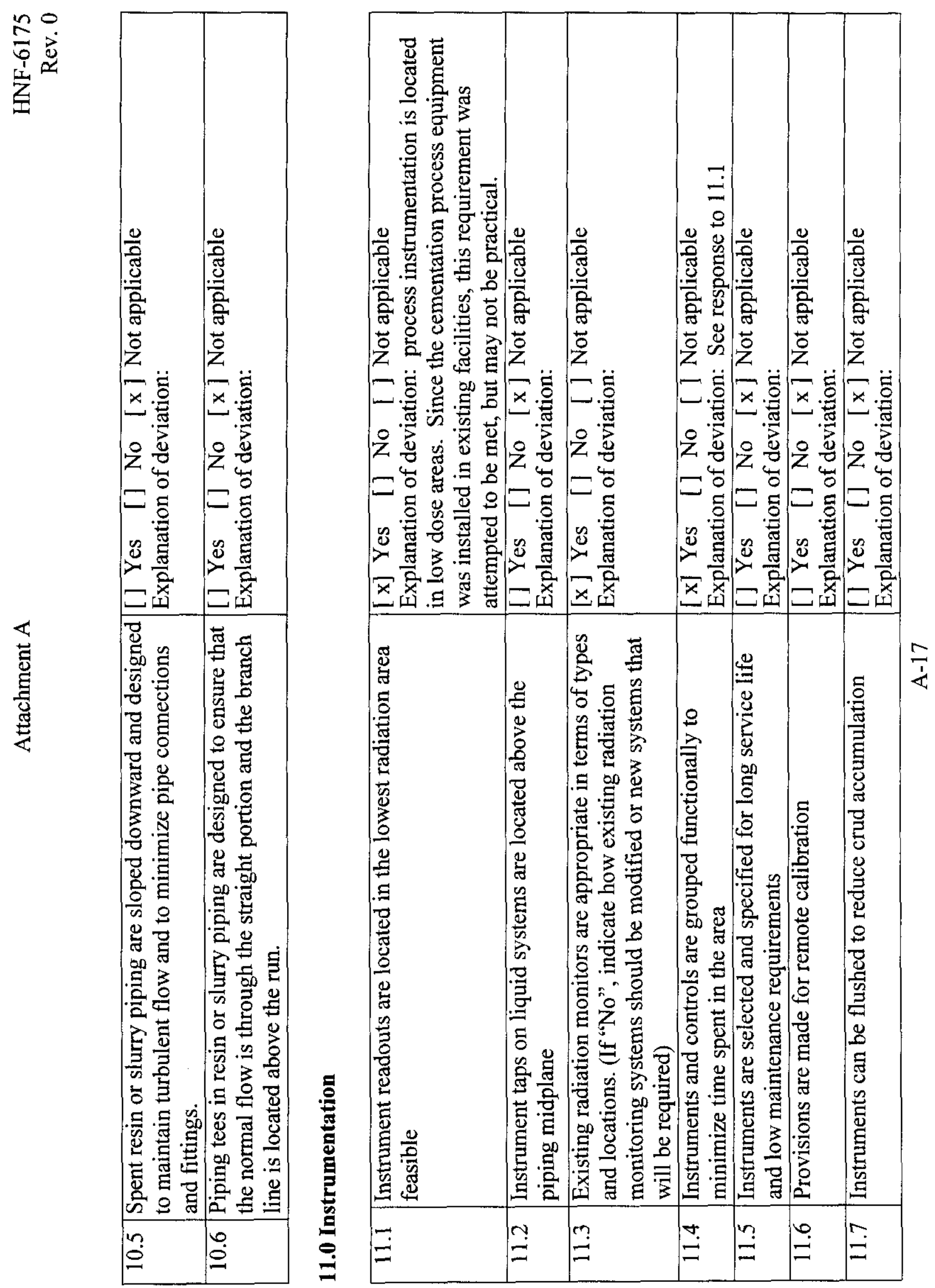


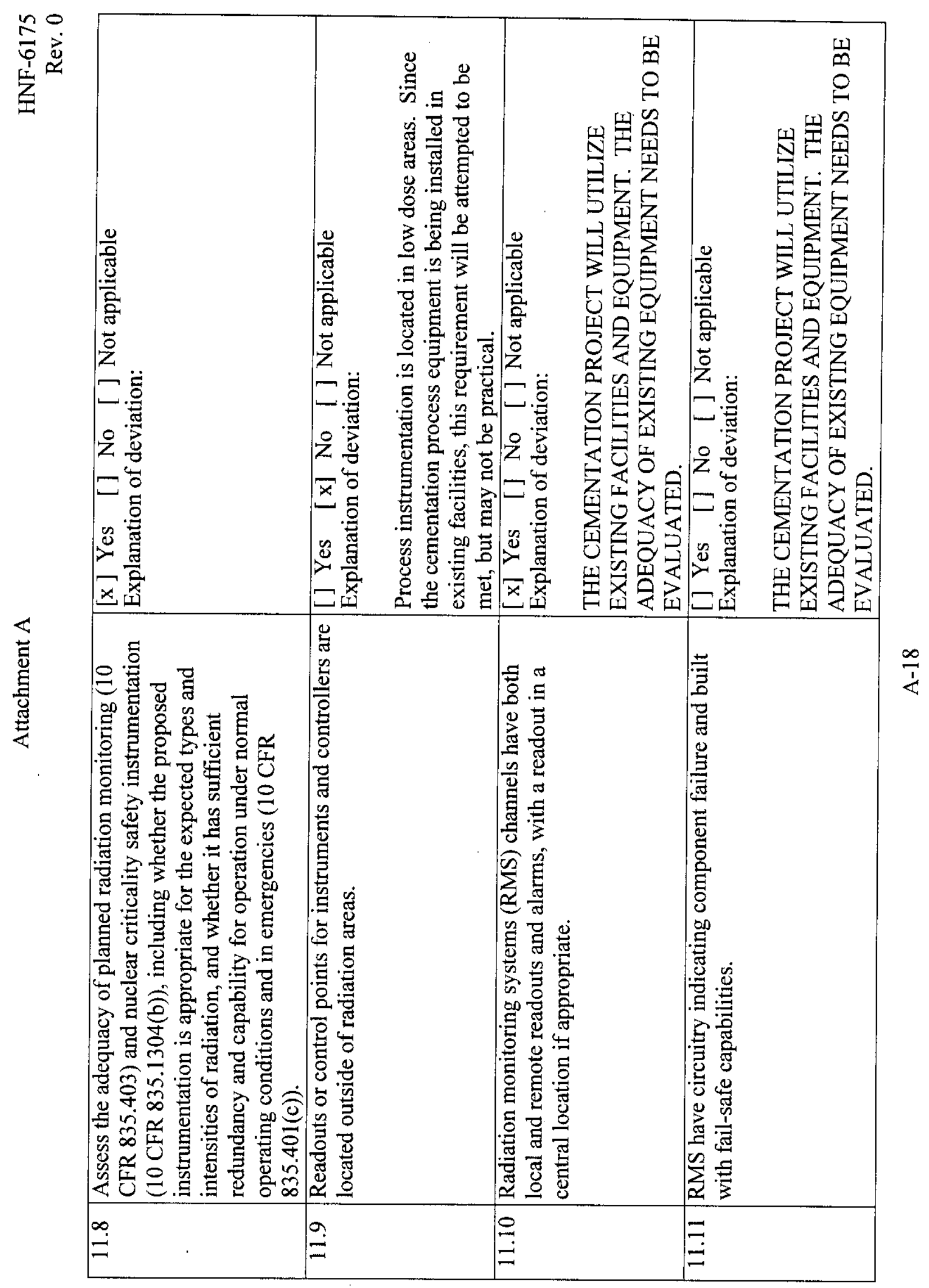



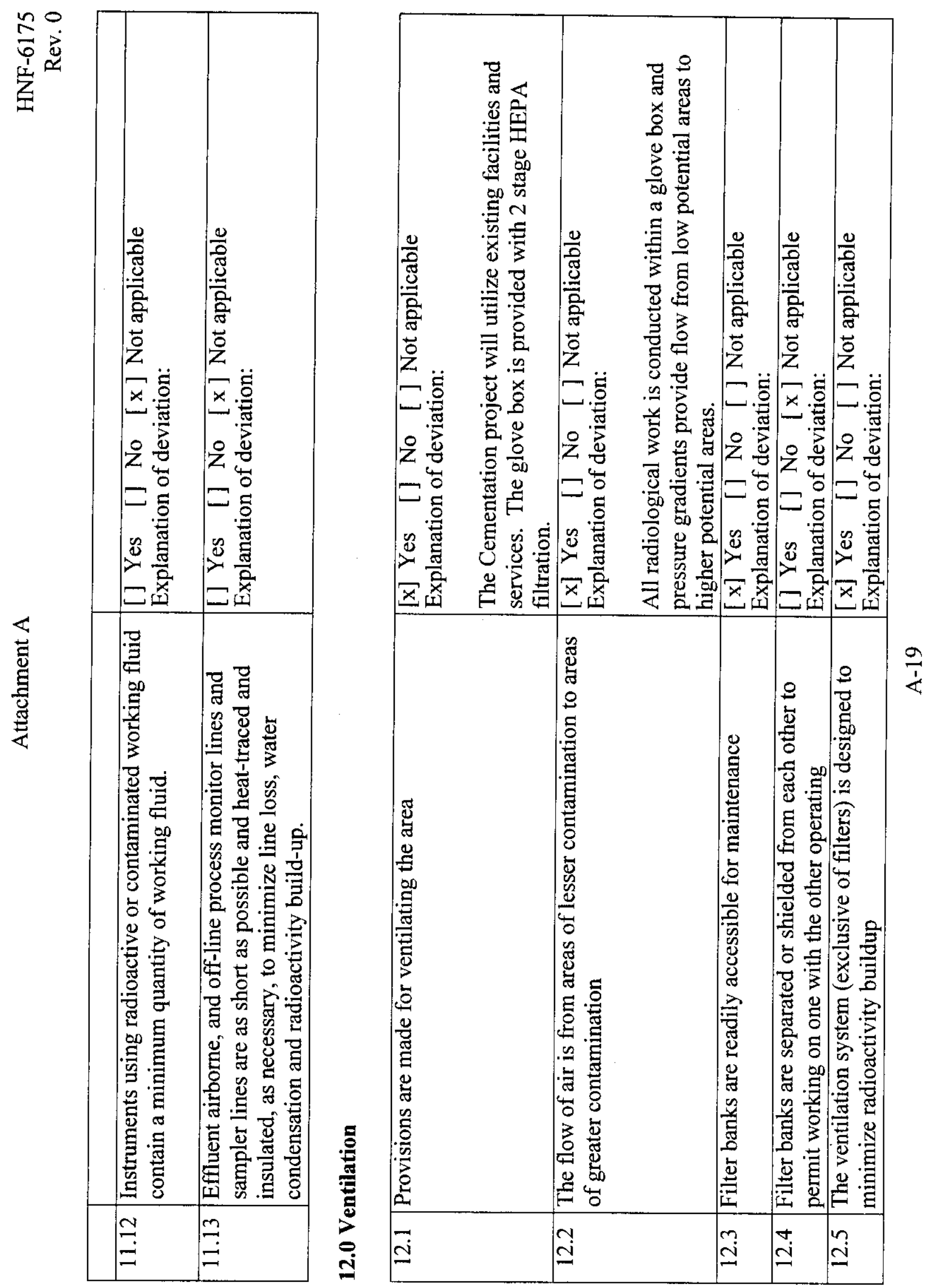


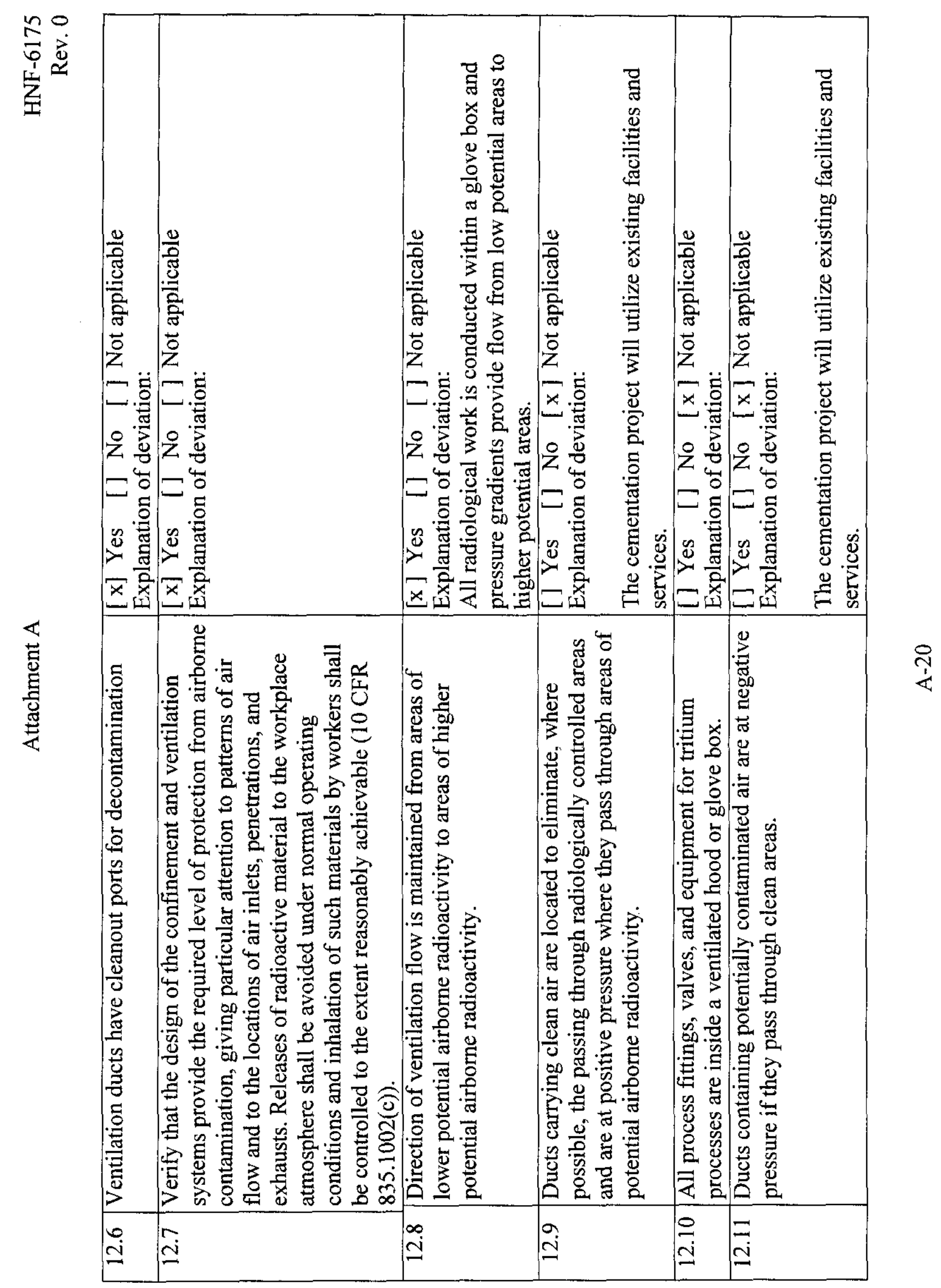




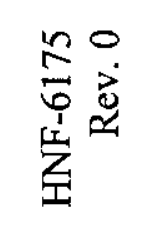

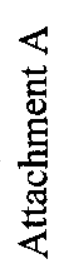

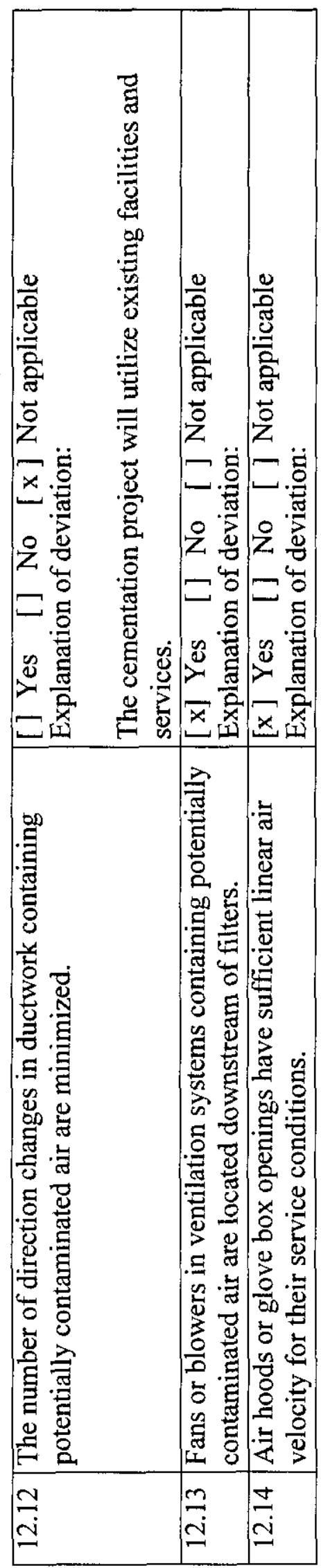

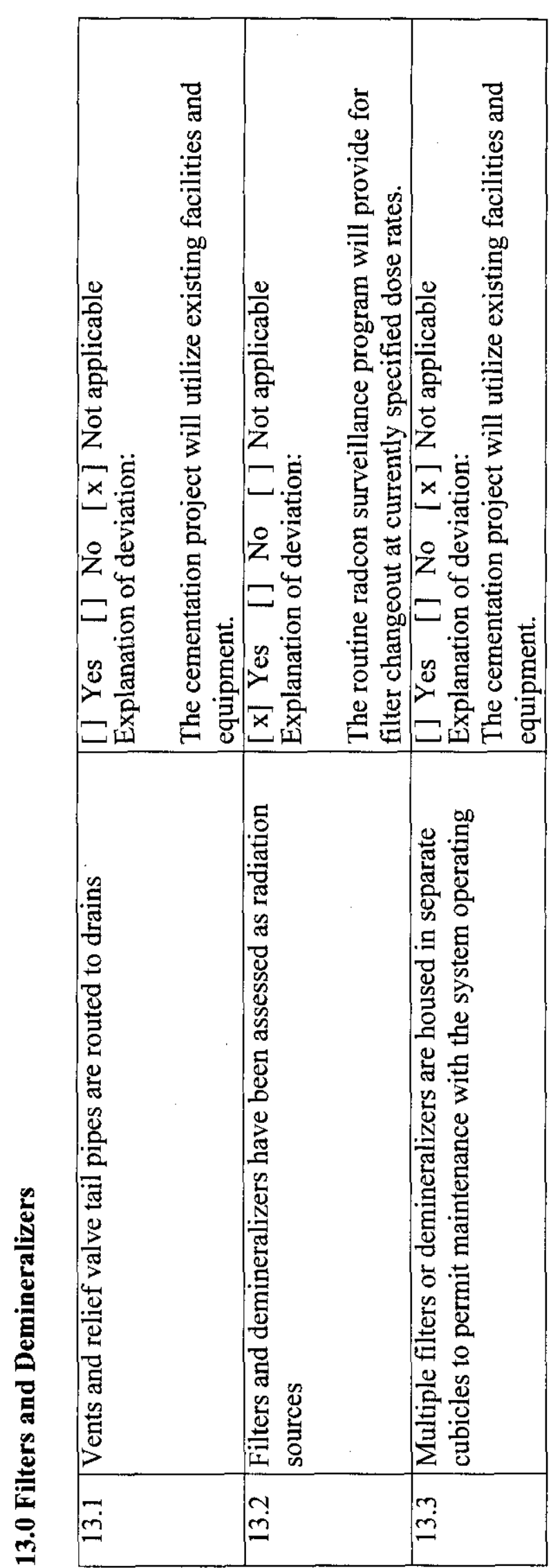



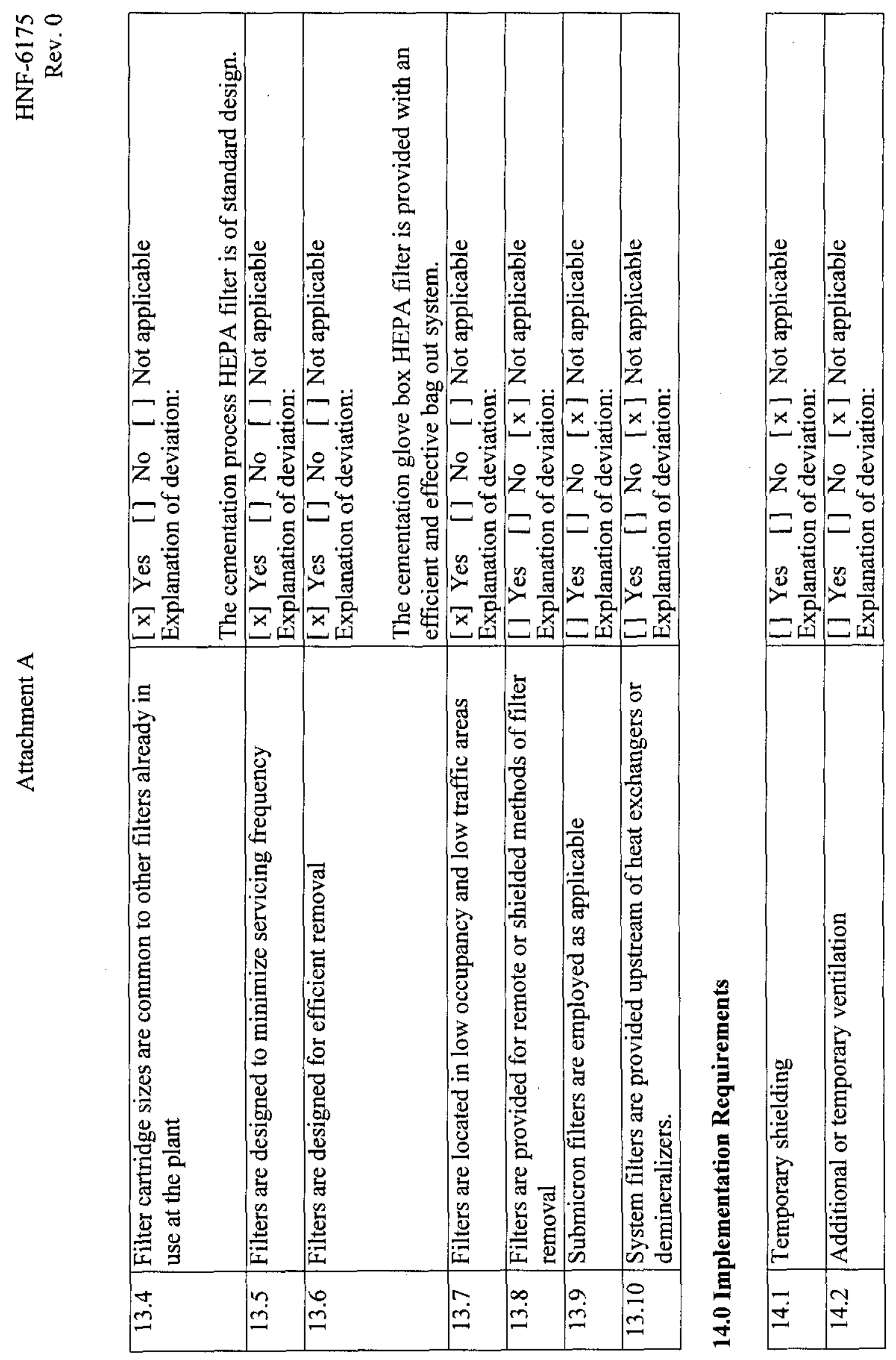

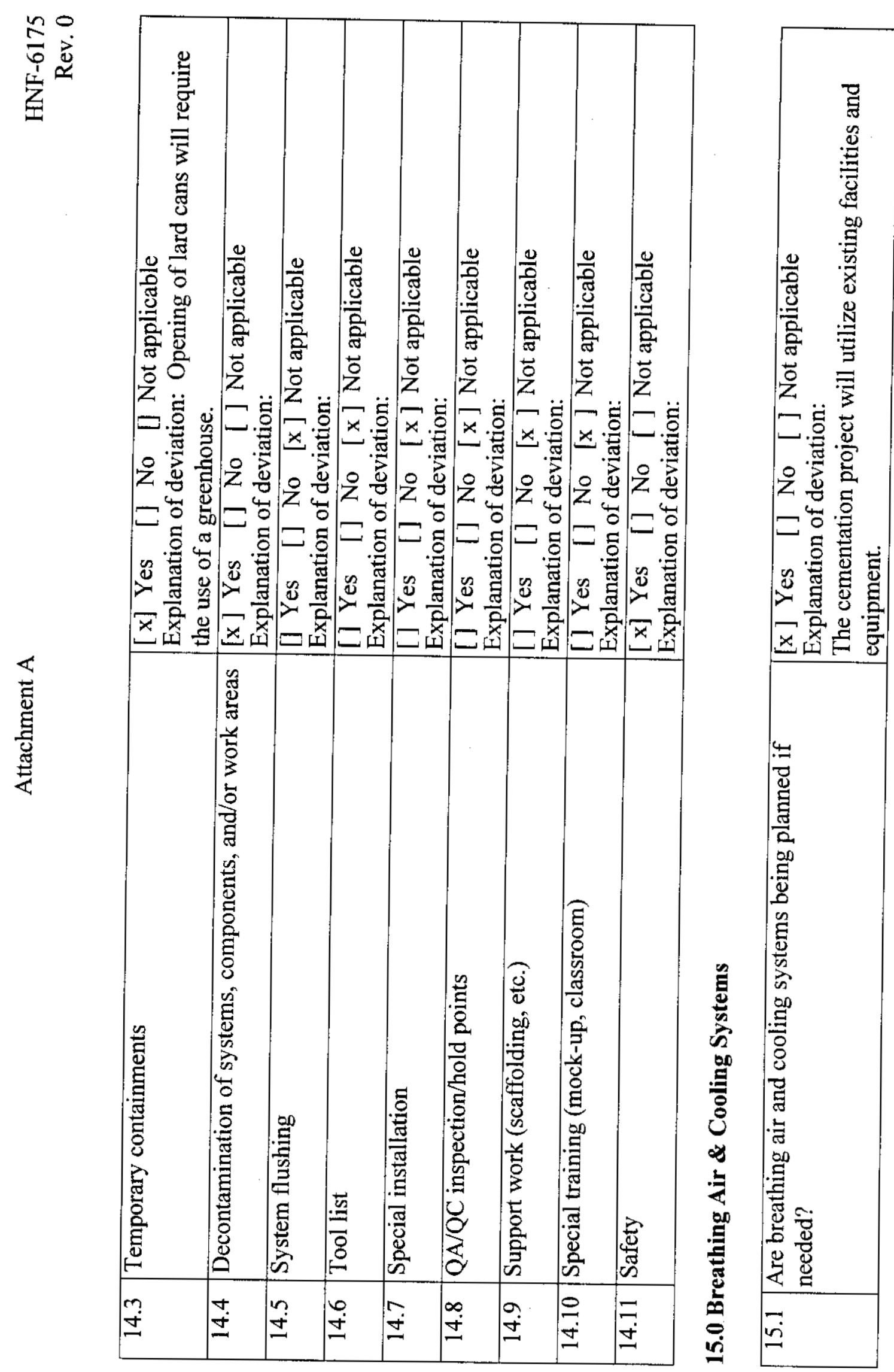

$\stackrel{9}{4}$ 


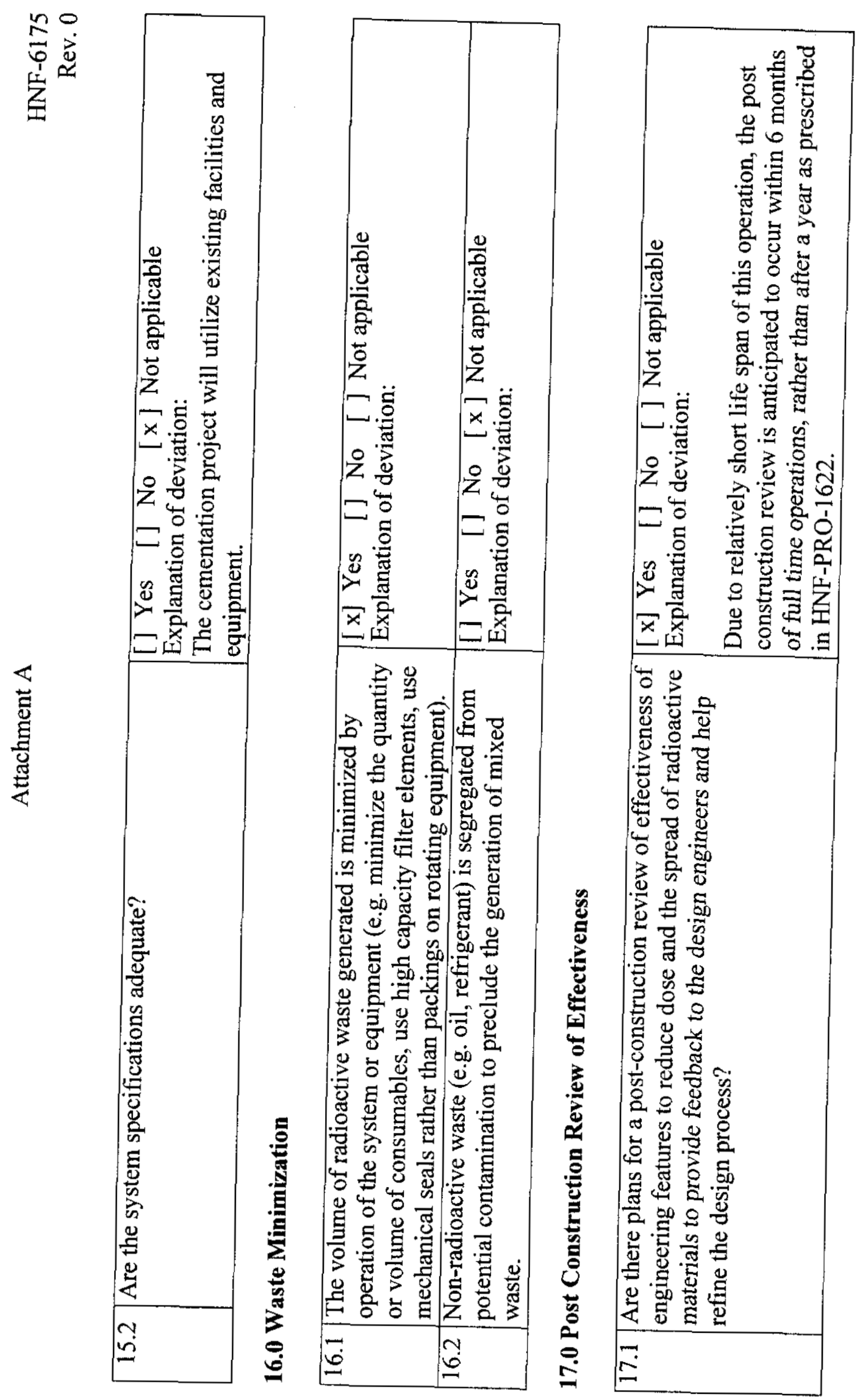

$\stackrel{+}{4}$ 

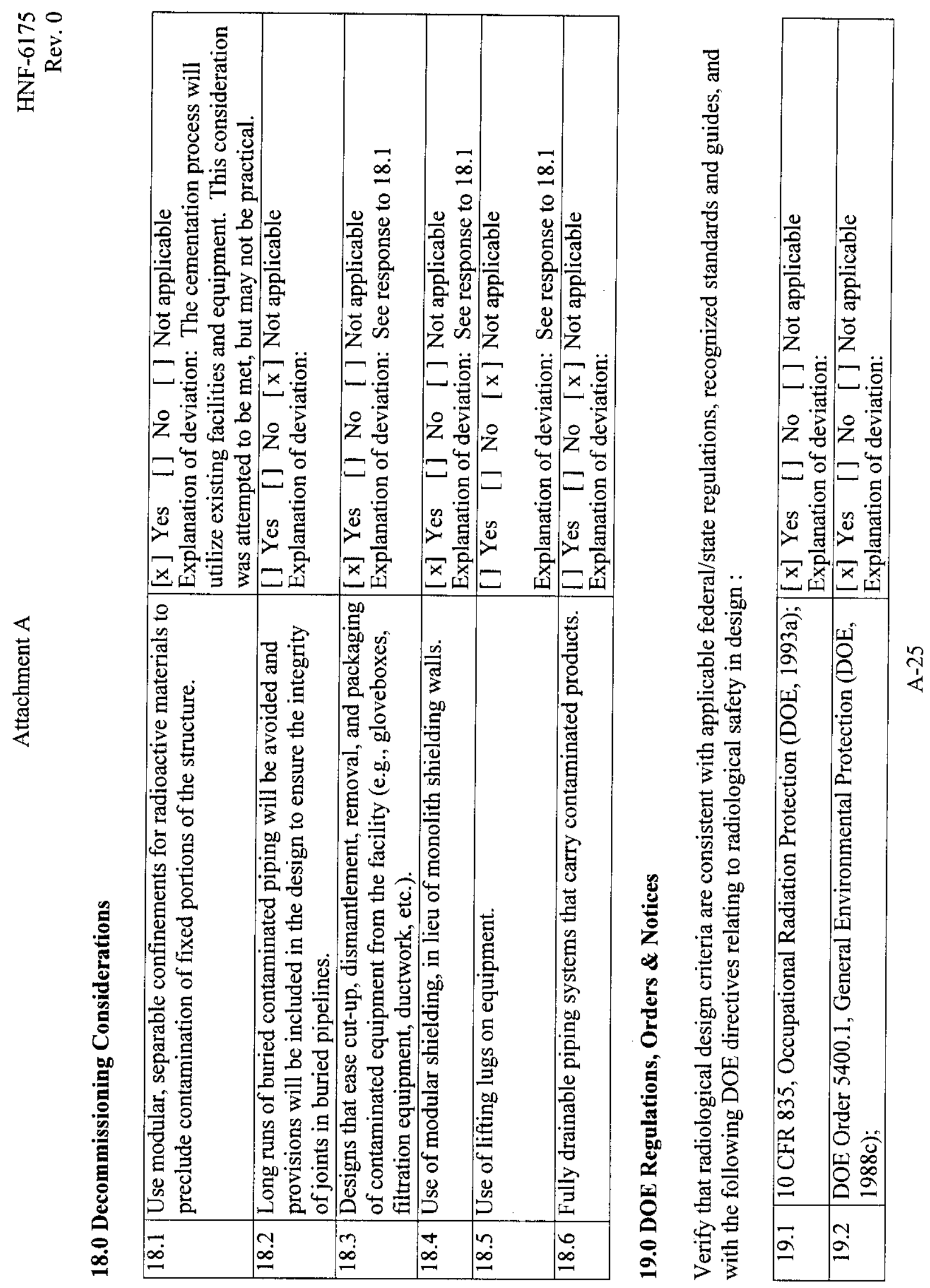

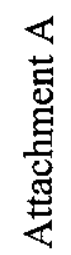



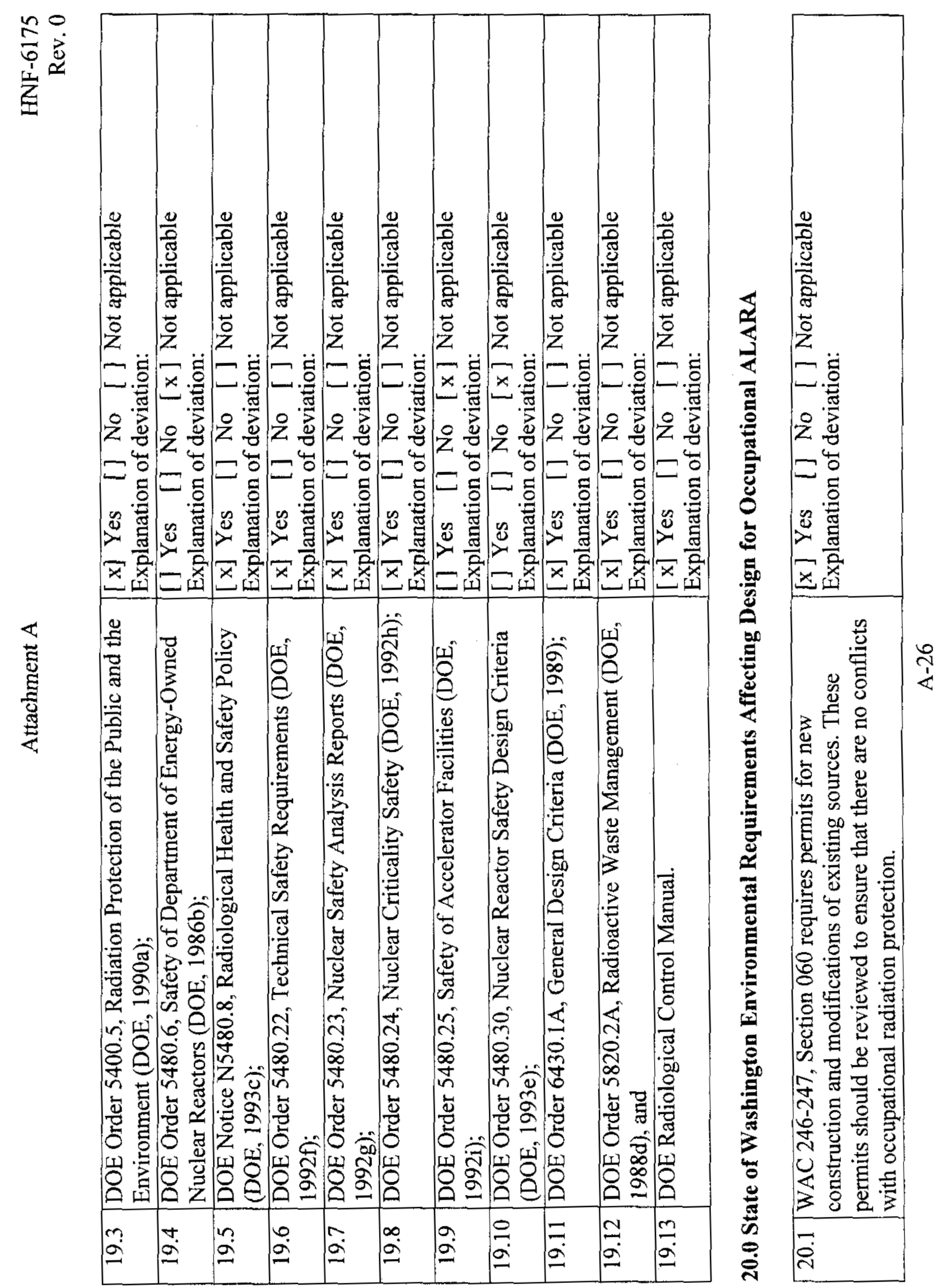

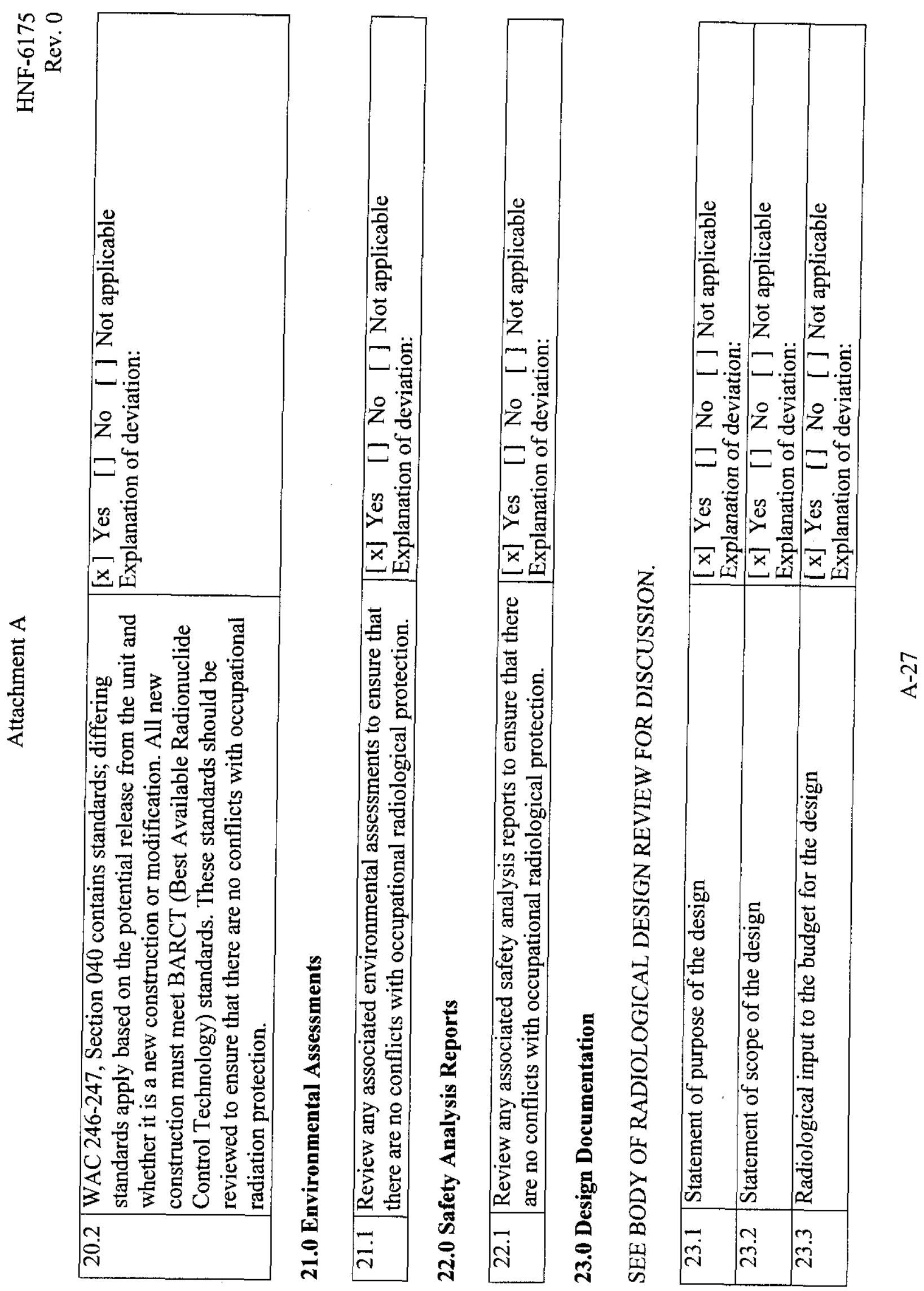

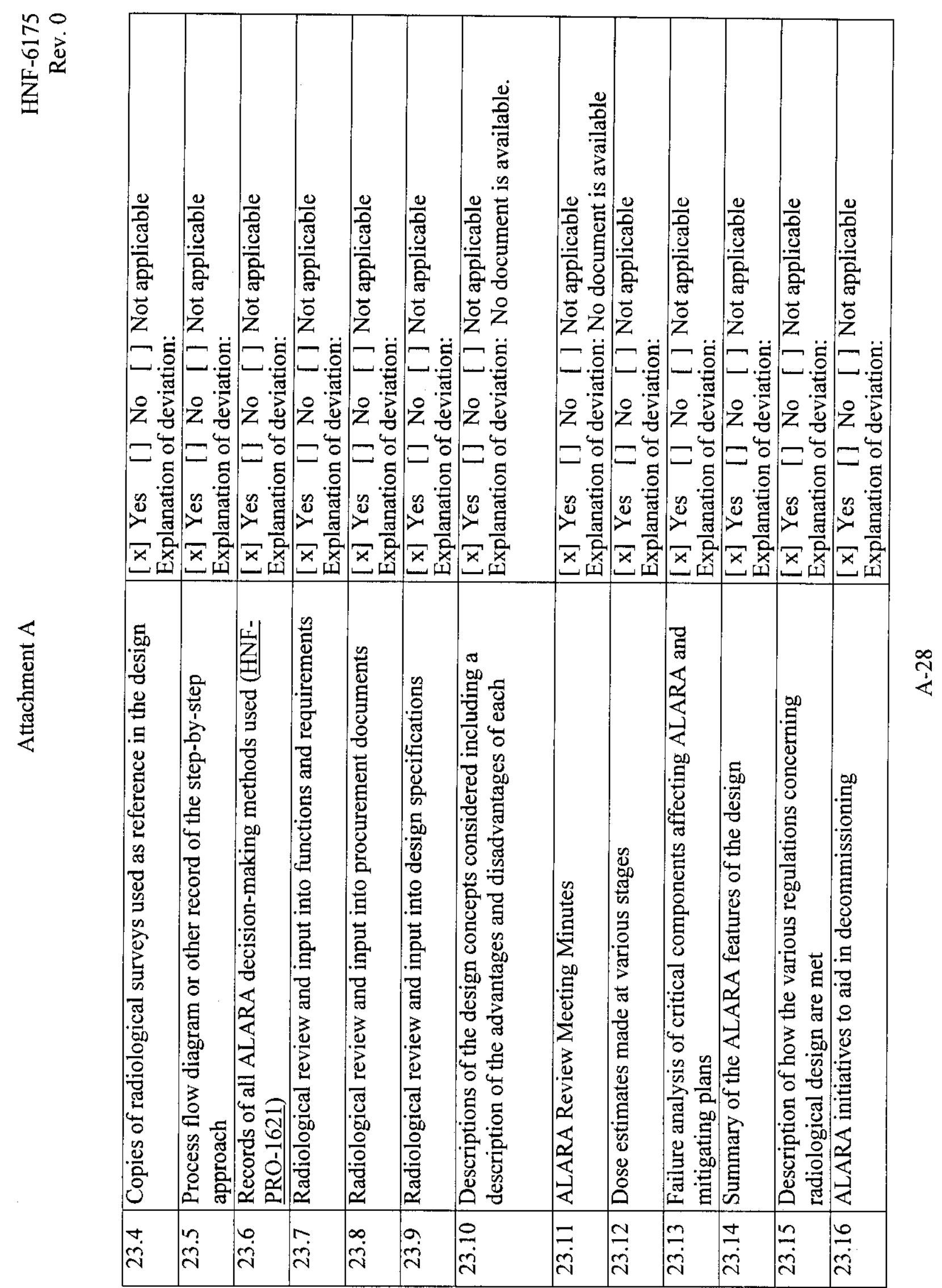


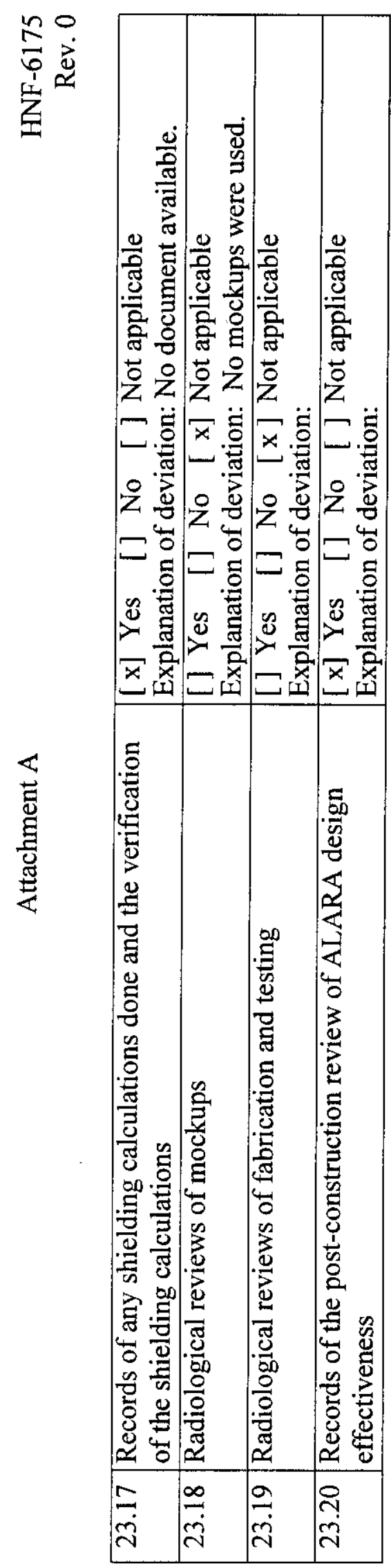

ชุ 


\section{Cementation Project Dose Summary, Timeline and Assumptions}

\section{I) Project Dose Summary}

\begin{tabular}{|l|l|l|l|}
\multicolumn{4}{|c}{ Activity } \\
\hline 1 & $\begin{array}{l}\text { Vault Access- Remove and load containers } \\
\text { (individual cans/lard cans) of plutonium } \\
\text { materials (SS\&C and Residues) stored in the } \\
\text { PFP vaults for transport. }\end{array}$ & $4.09 \mathrm{E}+3$ & $4.21 \mathrm{E}+3$ \\
\hline 2 & $\begin{array}{l}\text { Move Containers to 235-B Temporary } \\
\text { Storage Area- Transport, transfer custody, } \\
\text { and unload containers to 235-B temporary } \\
\text { storage area. }\end{array}$ & $4.20 \mathrm{E}+2$ & $5.98 \mathrm{E}+2$ \\
\hline 3 & $\begin{array}{l}\text { Transport Lard Cans to HA 28/235 B } \\
\text { Containment- Load and transport lard cans } \\
\text { to the HA 28/235-B containment for opening. }\end{array}$ & $2.14 \mathrm{E}+2$ & $2.70 \mathrm{E}+2$ \\
\hline 4 & $\begin{array}{l}\text { Open Lard Cans- Load lard cans into } \\
\text { containment, open lard cans, and } \\
\text { remove/survey individual cans. }\end{array}$ & $5.70 \mathrm{E}+3$ & $7.25 \mathrm{E}+3$ \\
\hline 5 & $\begin{array}{l}\text { Move Containers to NDA- Load, transport } \\
\text { and unload containers from 235-B storage } \\
\text { area or containment to NDA for assay. }\end{array}$ & $4.44 \mathrm{E}+3$ & $5.95 \mathrm{E}+3$ \\
\hline 6 & $\begin{array}{l}\text { NDA Containers- Perform Segmented } \\
\text { Gamma Ray Scan assay of containers. }\end{array}$ & $1.61 \mathrm{E}+3$ & $2.11 \mathrm{E}+3$ \\
\hline 7 & $\begin{array}{l}\text { Move Containers to Cementation Glove } \\
\text { Box- Load transport wagon and transport } \\
\text { assayed containers to the Cementation Glove } \\
\text { Box. }\end{array}$ & $2.66 \mathrm{E}+3$ & $3.16 \mathrm{E}+3$ \\
\hline 8 & $\begin{array}{l}\text { Load In Containers- Load individual cans } \\
\text { into the Cementation Glove Box. }\end{array}$ & $2.76 \mathrm{E}+3$ & $3.26 \mathrm{E}+3$ \\
\hline 9 & $\begin{array}{l}\text { Cementing Operations- Immobilize } \\
\text { plutonium materials in cement matrix. }\end{array}$ & $1.44 \mathrm{E}+4$ & $3.27 \mathrm{E}+4$ \\
\hline 10 & $\begin{array}{l}\text { Seal Out of Cemented Containers- Seal out } \\
\text { grouted waste from the Glove Box. }\end{array}$ & $2.64 \mathrm{E}+3$ & $7.53 \mathrm{E}+3$ \\
\hline
\end{tabular}




\begin{tabular}{|l|l|l|l|}
\hline 11 & $\begin{array}{l}\text { Load Cylinders into Pipe Overpack } \\
\text { Containers-Load cemented containers into } \\
\text { Pipe Overpack Containers. }\end{array}$ & $1.90 \mathrm{E}+3$ & $2.59 \mathrm{E}+3$ \\
\hline 12 & $\begin{array}{l}\text { Move Drums to Staging Area- Transport } \\
\text { drums to staging area for transport/shipment } \\
\text { to storage facility. }\end{array}$ & $1.88 \mathrm{E}+2$ & $1.88 \mathrm{E}+2$ \\
\hline & Total Dose - All personnel & $4.10 \mathrm{E}+4$ & $6.98 \mathrm{E}+4$ \\
\hline & Annual Dose & $1.09 \mathrm{E}+4$ & $1.85 \mathrm{E}+4$ \\
\hline & Annual Average Operator Dose & 853 & 1588 \\
\hline
\end{tabular}

\section{II) Timeline/Assumptions}

\section{Vault Access}

To estimate the total worker dose for this step, the following assumptions were made:

- 166 Lard cans require movement from vault.

- 12 Individual cans require movement from vault.

- The configuration of the lard can limits the maximum number of individual cans in each lard can to 12 . It is assumed that there will be an average of 9 individual cans in each lard can.

- 178 Items of material to be removed from vault and loaded on to the transport wagons.

- Basic dose rates assume weapons grade plutonium with an average $270 \mathrm{~g}$ of Pu per item/can for non-lard cans, and a range of 70 to $400 \mathrm{~g} \mathrm{Pu}$ for each lard can, with 50 to $60 \mathrm{~g} \mathrm{Pu}$ per individual can.

- Two vault operators, one vault technician, and one radcon technician would be involved in the removal of the 178 cans from the vault. Both operators would enter vault to remove cans while the vault technician and radcon technician would remain outside for support. On the average it would take 5 minutes to enter the vault, locate two lard cans or five individual cans and move them to the portal for removal. At the portal, it would then take another 5 minutes to survey the cans, fill in custody paperwork, and move them to transport wagon. Personnel would receive dose rates in the vault of $60 \mathrm{mrem} / \mathrm{hr}$ ( 50 to $70 \mathrm{mrem} / \mathrm{hr}$ range) 
background, $20 \mathrm{mrem} / \mathrm{hr}$ (10 to $30 \mathrm{mrem} / \mathrm{hr}$ range) on contact, and 4 $\mathrm{mrem} / \mathrm{hr}$ ( 2 to $6 \mathrm{mrem} / \mathrm{hr}$ range) at $30 \mathrm{~cm}$. Background dose rates outside the vault are $0.5 \mathrm{mrem} / \mathrm{hr}$.

- It would take two operators an average of 10 minutes to load the cans onto the transport wagons and place a shield blanket onto the wagon. The operators would receive an exposure at rates of $20 \mathrm{mrem} / \mathrm{hr}$ contact, 4 $\mathrm{mrem} / \mathrm{hr}$ at $30 \mathrm{~cm}$ and $0.5 \mathrm{mrem} / \mathrm{hr}$ background.

\section{Move Containers to 235-B Temporary Storage Area}

To estimate the total worker dose for this step, the following assumptions were made:

- The configuration of the transport wagons limit the loads to two lard cans or five individual cans. This establishes the definition of a batch or cycle for transport. Therefore 86 trips will be required to remove all cans from the vault.

- It would take two vault operators an average of 5 minutes per trip to transport the material to the custody transfer point. A lead acrylic blanket would be used to provide shielding. The first operator would receive a reduced exposure at a rate of $10 \mathrm{mrem} / \mathrm{hr}$ contact, $2 \mathrm{mrem} / \mathrm{hr}$ at $30 \mathrm{~cm}$ and $0.5 \mathrm{mrem} / \mathrm{hr}$ background. The second would receive a dose at background rates. No contact exposure expected during transport. The bounding whole body dose rate has been reduced by a factor of 2 to account for the shielding of the lead blanket.

- It would take two vault operators an average of 10 minutes to open the wagon, identify each item and transfer custody to the Solutions/Residues Stabilization Project (S/RSP) operators. The S/RSP operators would receive an exposure at rates of $20 \mathrm{mrem} / \mathrm{hr}$ contact, $4 \mathrm{mrem} / \mathrm{hr}$ at $30 \mathrm{~cm}$ and $0.5 \mathrm{mrem} / \mathrm{hr}$ background during the transfer.

- It would take two S/RSP operators an average of 5 minutes per trip to transport the containers to the 235-B Temporary Storage Area. A lead acrylic blanket would be used to provide shielding. The first operator would receive a reduced exposure at rate of $10 \mathrm{mrem} / \mathrm{hr}$ contact, 2 $\mathrm{mrem} / \mathrm{hr}$ at $30 \mathrm{~cm}$ and $0.5 \mathrm{mrem} / \mathrm{hr}$ background. The second would receive a dose at background rates. No contact exposure expected during transport. The bounding whole body dose rate has been reduced by a factor of 2 to account for the shielding of the lead blanket. It would take two S/RSP operators an average of 10 minutes to unload the cans at the temporary storage area. The operators would receive an exposure at rates of $20 \mathrm{mrem} / \mathrm{hr}$ contact, $4 \mathrm{mrem} / \mathrm{hr}$ at $30 \mathrm{~cm}$ and $0.5 \mathrm{mrem} / \mathrm{hr}$ background. 


\section{Transport Lard Cans to HA 28/235 B Containment}

To estimate the total worker dose for this step, the following assumptions were made:

- The configuration of the transport wagons limit the loads to two lard cans. This establishes the definition of a batch or cycle for transport. Therefore 83 trips will be required to remove all lard cans from the 235-B Storage Area.

- It would take two S/RSP operators an average of 10 minutes to load the two lard cans onto a transport wagon at the temporary storage area. The operators would receive an exposure at rates of $20 \mathrm{mrem} / \mathrm{hr}$ contact, 4 $\mathrm{mrem} / \mathrm{hr}$ at $30 \mathrm{~cm}$ and $0.5 \mathrm{mrem} / \mathrm{hr}$ background.

- It would take two operators an average of 5 minutes per trip to transport the lard cans to the containment for opening. A lead acrylic blanket would be used to provide shielding. The first operator would receive a reduced exposure rate of $10 \mathrm{mrem} / \mathrm{hr}$ contact, $2 \mathrm{mrem} / \mathrm{hr}$ at $30 \mathrm{~cm}$ and $0.5 \mathrm{mrem} / \mathrm{hr}$ background. The second would receive a dose at background rates. No contact exposure expected during transport. The bounding whole body dose rate has been reduced by a factor of 2 to account for the shielding of the lead blanket.

\section{Open Lard Cans}

To estimate the total worker dose for this step, the following assumptions were made:

- It would take two operators an average of 10 minutes to unload the two cans and put them into the containment. The operators would receive an exposure at rates of $20 \mathrm{mrem} / \mathrm{hr}$ contact, $4 \mathrm{mrem} / \mathrm{hr}$ at $30 \mathrm{~cm}$ and 1 $\mathrm{mrem} / \mathrm{hr}$ background.

- The configuration of the lard can limits the number of Individual cans in each Lard can to a maximum of 12 . An average of 9 per lard can will be assumed for this calculation. Therefore a total of 1494 individual cans require removal from the greenhouse for NDA.

- It would take two operators and a radcon technician an average of 20 minutes to open the lard cans, remove the individual cans, survey, place cans in a ITC and remove the individual cans from the containment. The personnel would receive an exposure at rates of $20 \mathrm{mrem} / \mathrm{hr}$ contact, 4 $\mathrm{mrem} / \mathrm{hr}$ at $30 \mathrm{~cm}$ and $1 \mathrm{mrem} / \mathrm{hr}$ background. 


\section{Move Containers to NDA}

To estimate the total worker dose for this step, the following assumptions were made:

- All items removed from the vault will require NDA.

- The configuration of the transport wagons limit the loads to five individual cans. This establishes the definition of a batch or cycle for transport. Therefore 302 trips will be required to move all 1506 individual cans from the 235-B Storage Area and HA 28/235 B Containment to NDA.

- It would take two S/RSP operators an average of 10 minutes to load five individual cans onto a transport wagon at the temporary storage area or greenhouse. The operators would receive an exposure at rates of 20 $\mathrm{mrem} / \mathrm{hr}$ contact, $4 \mathrm{mrem} / \mathrm{hr}$ at $30 \mathrm{~cm}$ and $0.5 \mathrm{mrem} / \mathrm{hr}$ background.

- It would take two operators and a radcon technician an average of 10 minutes per trip to move the individual containers from the temporary storage area or the containment area to the NDA Lab. A lead acrylic blanket would be used to provide shielding. The personnel would receive a reduced exposure at rate of $10 \mathrm{mrem} / \mathrm{hr}$ contact, $2 \mathrm{mrem} / \mathrm{hr}$ at $30 \mathrm{~cm}$ and $0.5 \mathrm{mrem} / \mathrm{hr}$ background. No contact exposure expected during transport. The bounding whole body dose rate has been reduced by a factor of 2 to account for the shielding of the lead blanket.

- It would take two operators an average of 10 minutes to unload five individual cans at NDA. The operators would receive an exposure at rates of $20 \mathrm{mrem} / \mathrm{hr}$ contact, $4 \mathrm{mrem} / \mathrm{hr}$ at $30 \mathrm{~cm}$ and $2 \mathrm{mrem} / \mathrm{hr}$ background (1 to $3 \mathrm{mrem} / \mathrm{hr}$ range).

\section{NDA Containers}

To estimate the total worker dose for this step, the following assumptions were made:

- All 1506 cans brought to NDA will undergo segmented gamma ray scan assay. Estimated time for performing the scan is 30 minutes.

- NDA personnel performing the assay will be in contact with material for approximately 1 minute and receive exposure at rates of $20 \mathrm{mrem} / \mathrm{hr}$ contact, $4 \mathrm{mrem} / \mathrm{hr}$ at $30 \mathrm{~cm}$ and $2 \mathrm{mrem} / \mathrm{hr}$ background.

\section{Move Containers to Cementation Glove Box}

To estimate the total worker dose for this step, the following assumptions were made: 
- It would take two operators an average of 10 minutes to load five cans onto the wagon and place a shield blanket onto the wagon. The operators would receive an exposure at rates of $20 \mathrm{mrem} / \mathrm{hr}$ contact, $4 \mathrm{mrem} / \mathrm{hr}$ at 30 $\mathrm{cm}$ and $0.5 \mathrm{mrem} / \mathrm{hr}$ background.

- The configuration of the transport wagons limit the loads to five individual cans. This establishes the definition of a batch or cycle for transport. Therefore 302 trips will be required to move all individual cans from NDA to the Cementation glove box area.

- It would take two operators an average of 10 minutes per trip. A lead acrylic blanket would be used to provide shielding. The first operator would receive a reduced exposure at rate of $10 \mathrm{mrem} / \mathrm{hr}$ contact, 2 $\mathrm{mrem} / \mathrm{hr}$ at $30 \mathrm{~cm}$ and $0.5 \mathrm{mrem} / \mathrm{hr}$ background. The second would receive a dose at background rates. No contact exposure expected during transport. The bounding whole body dose rate has been reduced by a factor of 2 to account for the shielding of the lead blanket.

\section{Load In Containers}

To estimate the total worker dose for this step, the following assumptions were made:

- It would take two operators and a radcon technician an average of 10 minutes to load each of the 302 batch/cycle of cans into the glove box. The first operator would receive an exposure at rate of $20 \mathrm{mrem} / \mathrm{hr}$ contact, $4 \mathrm{mrem} / \mathrm{hr}$ at $30 \mathrm{~cm}$ and $1 \mathrm{mrem} / \mathrm{hr}$ background. The second operator and radcon technician would receive exposure at a background rate. (Note: Background rate assumed here does not include the contribution from the operation of the three new muffle furnaces.)

- These times assume that all insertion will be via the sphincter port, since all lard cans will have been opened prior to NDA.

- The configuration of the transport wagon limits the load to five individual cans per trip. Therefore load in will occur in groups of five. A total of 1506 cans will be loaded into the glove box.

\section{Cementing Operations}

To estimate the total worker dose for this step, the following assumptions were made:

- The processing rate is expected to be 1 slip lid can per hour or approximately 8 to $10 \mathrm{slip}$ lid cans of cemented material per day. Each cemented container would contain up to $60 \mathrm{~g}$ of Pu. Tasks and associated times per cycle/batch are: 
- Weigh and open feed items

- Sieve and Grind

- Transfer and weigh reaction charge

-Load auger, prepare mixer and

start auger

-Monitor reaction and control foam

-Weigh slip lid can and add material

-Weigh, add cement and mix

-Pour cement and let set

Total
20 mins.

30 mins.

20 mins.

35 mins.

100 mins

40 mins

45 mins.

15 mins.

305 mins.

- It would take three operators an average of 305 minutes to process each batch/cycle of cans into the glove box. This time is broken up into the following batches: $302 @ 105$ mins. (based on batches/cycles) and 1506 (a) 200 mins (based on one for one cementation for each individual can). The first two operators would receive an exposure at rate of $8 \mathrm{mrem} / \mathrm{hr}$ contact, $1.6 \mathrm{mrem} / \mathrm{hr}$ at $30 \mathrm{~cm}$ and $1 \mathrm{mrem} / \mathrm{hr}$ background. The bounding contact and whole body dose rate has been reduced by a factor of 2.5 to account for the shielding of the Glove Box and gloves. The third operator would receive exposure at a background rate. (Note: The background rate assumed here does not include the contribution from the operation of the three new muffle furnaces.)

\section{Seal Out of Cemented Containers}

To estimate the total worker dose for this step, the following assumptions were made:

- Based on information contained above, 1506 cemented slip lid cans will be required to be sealed out and unloaded from the glove box.

- Sealing out a cemented container from the glove box would involve two operators and a radcon technician. Both operators would handle the container for approximately 10 and 5 minutes respectively. Both would receive dose at an exposure rate of $13 \mathrm{mrem} / \mathrm{hr}$ contact, $2.5 \mathrm{mrem} / \mathrm{hr}$ at 30 $\mathrm{cm}$ and $1 \mathrm{mrem} / \mathrm{hr}$ background. The bounding contact and whole body dose rate has been reduced by a factor of 1.5 to account for the selfshielding in the cement matrix. The radcon technician would receive dose at both handling and background levels for a period of 10 minutes.

- Operators would place the sealed out container directly into the Pipe Overpack Container assembly. 


\section{Load Cylinders into Pipe Overpack Containers}

To estimate the total worker dose for this step, the following assumptions were made:

- Due to WIPP/WAC requirements the maximum allowed Pu in the Pipe Overpack Container is $200 \mathrm{~g}(+/$ - measurement error). At present it is estimated that only three, cemented slip lid containers, each containing approximately $60 \mathrm{~g} \mathrm{Pu}$, will be loaded into a Pipe Overpack Container. This number may revised based on container content and NDA WIPP/WAC requirements.

- It would take an operator an average of 20 minutes to load 3 slip lid containers and bolt the lid onto the Pipe container. The first operator would receive an exposure at rate of $13 \mathrm{mrem} / \mathrm{hr}$ contact, $2.5 \mathrm{mrem} / \mathrm{hr}$ at $30 \mathrm{~cm}$ and $0.5 \mathrm{mrem} / \mathrm{hr}$ background. The second would receive a dose at background rates.

- Due to the configuration of the overpack drums, only one cylinder will fit into each drum. Therefore 502 drums will be loaded with cylinders.

- It would take an operator an average of 10 minutes to seal the drum. The first operator would receive an exposure at rate of $4 \mathrm{mrem} / \mathrm{hr}$ contact, 0 $.75 \mathrm{mrem} / \mathrm{hr}$ at $30 \mathrm{~cm}$ and $0.5 \mathrm{mrem} / \mathrm{hr}$ background. The second would receive a dose at background rates.

\section{Move Drums to Staging Areas}

To estimate the total worker dose for this step, the following assumptions were made:

- It would take two operators an average of 10 minutes per trip to move a drum dolly to the facility shipment staging/storage area. The first operator would receive a reduced exposure at rate of $4 \mathrm{mrem} / \mathrm{hr}$ contact, 0.75 $\mathrm{mrem} / \mathrm{hr}$ at $30 \mathrm{~cm}$ and $0.5 \mathrm{mrem} / \mathrm{hr}$ background. No contact exposure is expected during this transport. The second would receive a dose at background rates.

- A total of 502 drums will be moved to the facility shipment staging/storage area. 


\section{Annual and Average Operator Dose}

To estimate the total worker and average operator dose, the following assumptions were made:

- Personnel will work 50 weeks per year, 2 shifts per day, 5 days per week and complete cementation of 2 batches per shift. This assumes an average work off of 400 batches per year.

- Based on the assumption that 1506 cans/items will be cemented one for one into cemented containers, it will take 3.8 years to complete task.

- Crew sizes to accomplish this task per shift 5 S/RSP Operators, 3 Vault personnel, 1 NDA personnel and 1 Radiation Control technician.

- Most limiting dose group would be the S/RSP Operators. Based on an annual average dose of 853 mrem per year per FTE. Other group annual average dose per year per FTE would be 180 for Vault personnel, 213 for NDA personnel, and 432 for Radiation Control personnel. Therefore, all groups are under the design criteria of $1000 \mathrm{mrem} / \mathrm{yr}$ TEDE.

\section{References:}

1. PFP Stabilization Dose Equivalent Estimate, Mel Chew and Assoc., 1995

2. ALARA Assessment for HA-20MB Cementation Process, Internal Memo 15530-96-MWG-099, 1996

3. Analysis of Immobilization Alternatives, EIS-0244-F

4. PFP Survey Data for Vaults and Cementation Glove Box Areas, 2/00

5. Notes of Telecons with Cognizant Engineer and Experienced Operations Personnel. 


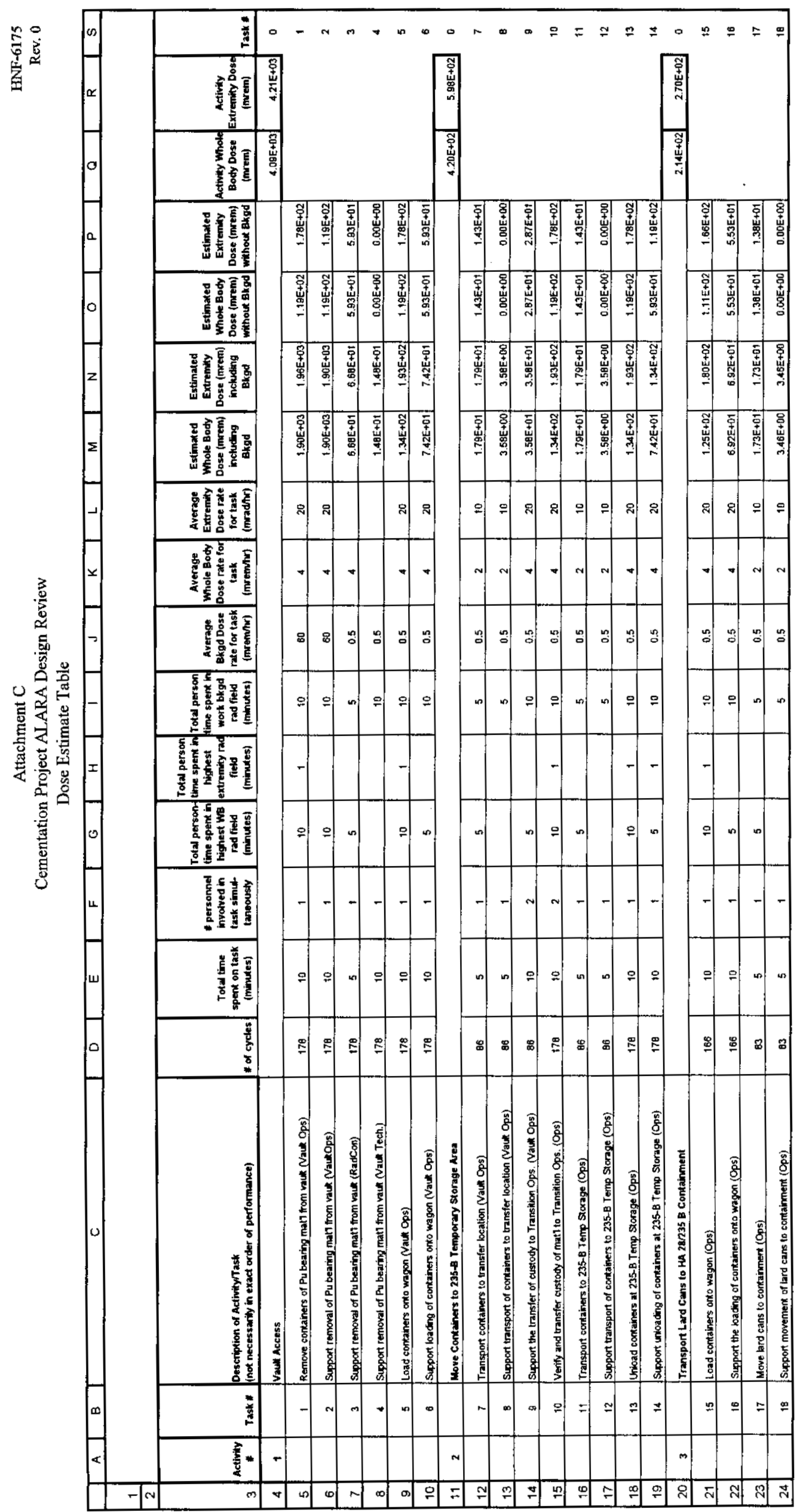




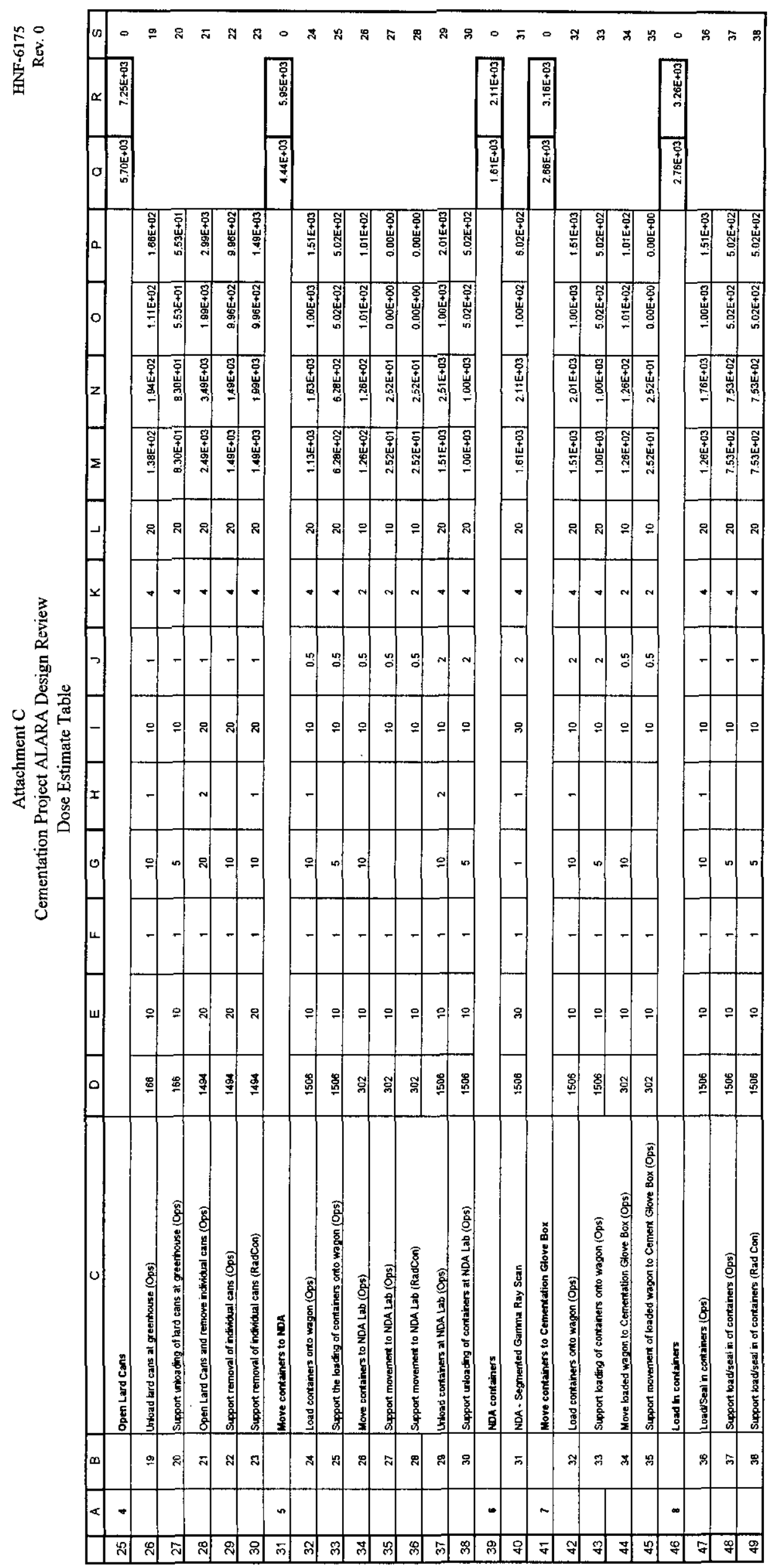




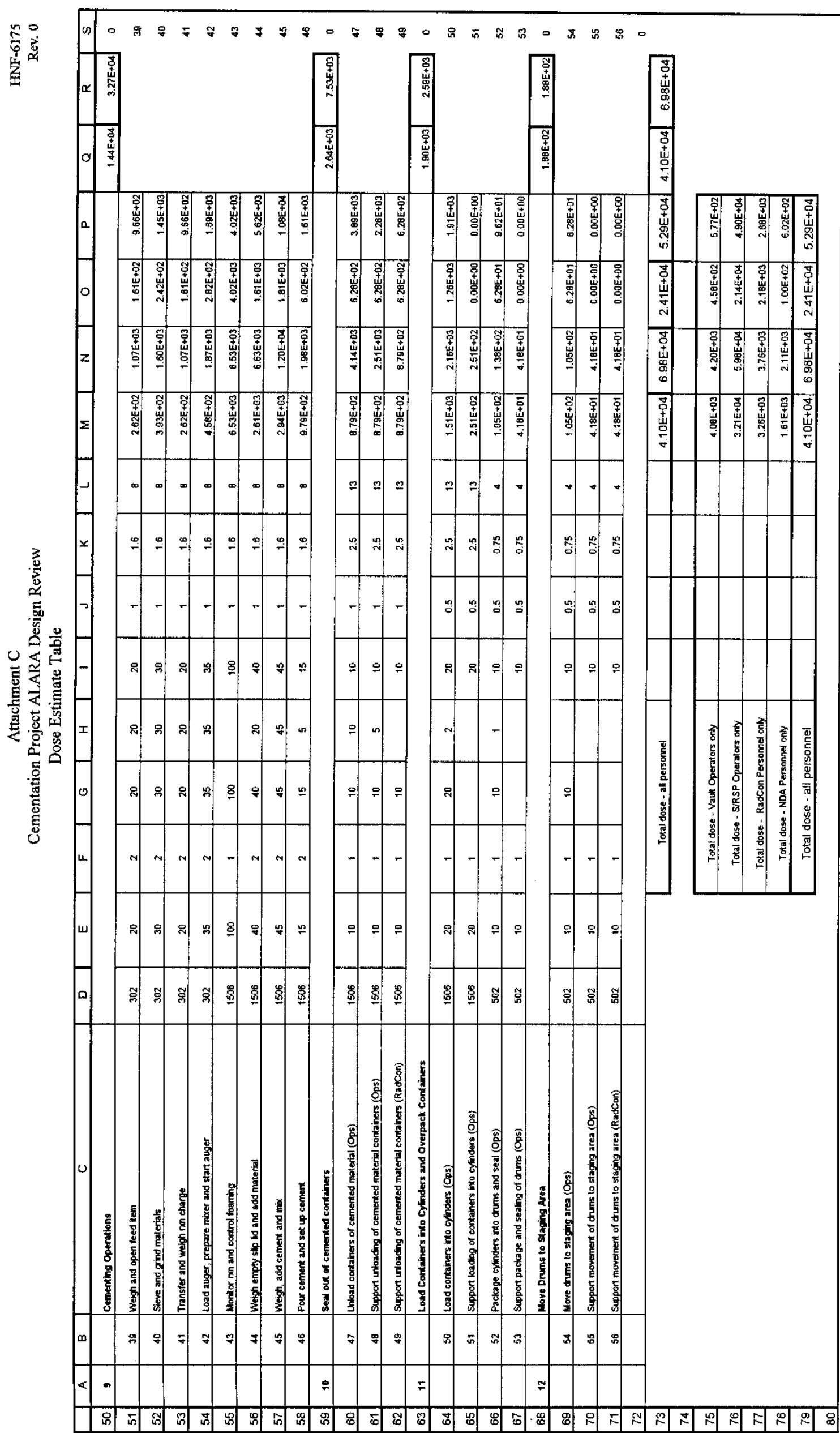

